\title{
Spotlight on ceritinib in the treatment of ALK+ NSCLC: design, development and place in therapy
}

\author{
This article was published in the following Dove Press journal: \\ Drug Design, Development and Therapy \\ 5 July 2017 \\ Number of times this article has been viewed
}

\section{Mariacarmela Santarpia' \\ Maria Grazia Daffinà' \\ Alessandro D'Aveni' \\ Grazia Marabello' \\ Alessia Liguori' \\ Elisa Giovannetti ${ }^{2-4}$ \\ Niki Karachaliou ${ }^{5}$ \\ Maria Gonzalez $\mathrm{Cao}^{6}$ \\ Rafael Rosell7,8 \\ Giuseppe Altavilla'}

'Medical Oncology Unit, Department of Human Pathology "G. Barresi”, University of Messina, Messina, Italy; ${ }^{2}$ Department of Medical Oncology,

VU University Medical Center,

Amsterdam, The Netherlands;

${ }^{3}$ Department of Nanoscience

and Nanotechnologies, CNR-

Nano, Institute of Nanoscience

and Nanotechnology, ${ }^{4}$ Cancer

Pharmacology Lab, AIRC Start-Up

Unit, University of Pisa, Pisa, Italy;

${ }^{5}$ Institute of Oncology Rosell (IOR),

University Hospital Sagrat Cor,

${ }^{6}$ Oncology Department, Institute of Oncology Rosell (IOR), Quirón-

Dexeus University Institute,

Barcelona, ${ }^{7}$ Cancer Biology and

Precision Medicine Program, Germans

Trias i Pujol Research Institute,

${ }^{8}$ Catalan Institute of Oncology,

Germans Trias i Pujol University

Hospital, Badalona, Spain
Correspondence: Mariacarmela Santarpia Medical Oncology Unit, Department of Human Pathology "G. Barresi”, University of Messina, Via Consolare Valeria, n. I, Messina, Italy

Tel +39090 22I 7002

Fax +39090 221 3231

Email msantarpia@unime.it

\begin{abstract}
The identification of echinoderm microtubule-associated protein-like 4 (EML4) and anaplastic lymphoma kinase $(A L K)$ fusion gene in non-small cell lung cancer (NSCLC) has radically changed the treatment of a subset of patients harboring this oncogenic driver. Crizotinib was the first ALK tyrosine kinase inhibitor to receive fast approval and is currently indicated as the first-line therapy for advanced, $A L K$-positive NSCLC patients. However, despite crizotinib's efficacy, patients almost invariably progress, with the central nervous system being one of the most common sites of relapse. Different mechanisms of acquired resistance have been identified, including secondary $A L K$ mutations, $A L K$ copy number alterations and activation of bypass tracks. Different highly potent and brain-penetrant next-generation ALK inhibitors have been developed and tested in NSCLC patients with $A L K$ rearrangements. Ceritinib, a structurally distinct and selective ALK inhibitor, showed 20 times higher potency than crizotinib in inhibiting ALK and had activity against the most common crizotinib-resistant mutations, including L1196M and G1269A, in preclinical models. In Phase I and II studies, ceritinib demonstrated pronounced activity in both crizotinib-naïve and crizotinib-refractory patients, with responses observed regardless of the presence of $A L K$ resistance mutations. Ceritinib was the first ALK inhibitor to be approved for the treatment of crizotinib-refractory, $A L K$-rearranged NSCLC, and recent results from a Phase III study have demonstrated superior efficacy compared to standard chemotherapy in the first- and second-line setting. We provide an extensive overview of ceritinib from the design of the compound through preclinical data until efficacy and toxicity results from Phase I-III clinical studies. We review the molecular alterations associated with resistance to ceritinib and highlight the importance of obtaining tumor biopsy at progression to tailor therapy based upon the underlying resistance mechanism. We finally provide an outlook on novel rational therapeutic combinations.
\end{abstract}

Keywords: acquired resistance, anaplastic lymphoma kinase gene, non-small cell lung cancer, ALK tyrosine kinase inhibitors

\section{Introduction}

Lung cancer represents the leading cause of cancer-related mortality worldwide and is responsible for nearly one cancer death in five among both sexes. ${ }^{1}$ Non-small cell lung cancer (NSCLC), the most common type of lung cancer, includes adenocarcinoma, squamous cell carcinoma and large-cell carcinoma histosubtypes and is generally diagnosed at advanced stages. Systemic therapy is the standard of care for advanced NSCLC patients and, until recently, platinum-based chemotherapy has been the only available first-line therapeutic option. Bevacizumab, a monoclonal antibody anti-vascular endothelial growth factor, was approved in combination with first-line platinum-based chemotherapy based on modest overall survival (OS) improvement in patients with nonsquamous NSCLC. ${ }^{2,3}$ Another targeted agent, the anti-epidermal 
growth factor receptor (anti-EGFR) monoclonal antibody necitumumab, has been approved with gemcitabine and cisplatin as the first-line treatment of metastatic squamous NSCLC based on a 1.6-month survival increase for the combination compared to chemotherapy alone. ${ }^{4}$ However, there are no current validated predictive biomarkers to select patients for both antiangiogenic drugs and anti-EGFR monoclonal antibodies.

The discovery in some subsets of NSCLC, mainly adenocarcinoma, of a number of actionable oncogenic alterations, including $E G F R$ mutations and $A L K$ rearrangements, conferring unique sensitivity to inhibition by specific molecularly targeted agents, has opened a new era of personalized medicine for lung cancer. Based on recent developments, NSCLC is not anymore considered a single entity, but a heterogeneous disease including morphologically and molecularly distinct subsets of tumors characterized by different therapeutic vulnerabilities. ${ }^{5}$ The tyrosine kinase inhibitors (TKIs) targeting EGFR and ALK have consistently demonstrated superior efficacy compared to chemotherapy, and they currently represent the standard of care of these molecularly defined subgroups of NSCLC patients. ${ }^{6-8}$ Therefore, besides histopathologic assessments, molecular profiling of lung cancer has been rapidly incorporated into the diagnostic process to guide treatment decisions. ${ }^{9}$

\section{EML4/ALK in NSCLC}

The identification of the echinoderm microtubule-associated protein-like 4 (EML4)-anaplastic lymphoma kinase ( $A L K)$ fusion gene as an oncogenic driver in NSCLC in 2007 revolutionized the therapeutic management and improved the prognosis of the relatively small, but still relevant, subset of patients harboring this molecular alteration. ${ }^{10}$ The EML4-ALK fusion gene arises from a small inversion within the short arm of chromosome 2 that joins the $5^{\prime}$-end (encoding the NH2-terminal portion, including the coiledcoil domain) of the EML4 gene to the 3'-end (encoding the $\mathrm{COOH}$-terminal portion, including the tyrosine kinase domain) of the $A L K$ gene. The $A L K$ gene encodes for a protein of 1,620 amino acids that is a transmembrane tyrosine kinase receptor belonging to the insulin receptor superfamily. ALK has a probable role in the normal development and function of the nervous system. ${ }^{11-13}$ In adult human tissues, expression of ALK appears restricted to certain neuronal cells. Pleiotrophin and midkine have been postulated to be the activating ligands of ALK. Both factors have shown to induce neuronal growth, but are also implicated in other processes such as cell migration and angiogenesis. ${ }^{13-15}$ Gene amplification, activating mutations and chromosomal translocations with the formation of fusion genes may be responsible for ALK activation in tumor cells. ${ }^{16}$

The EML4-ALK fusion gene results in a chimeric oncoprotein that undergoes constitutive dimerization and activation of the tyrosine kinase function of ALK and its downstream signaling, including Ras/mitogen-activated protein kinase (MAPK), phosphatidylinositol-4,5-bisphosphate 3-kinase (PI3K)/protein kinase B (AKT) and Janus kinase (JAK)/signal transducer and activator of transcription pathways, which can promote cell proliferation, differentiation, and provide antiapoptotic signals. The ALK fusion product was demonstrated to be oncogenic in lung cancer and to drive transformation both in vitro and in vivo, thus suggesting its inhibition could represent an effective therapeutic strategy. ${ }^{17,18}$ Multiple variants of $E M L 4-A L K$ have been reported, at least 15, depending on different breakpoints in the EML4 fused to the kinase domain of $A L K$. The most common of them include variant 1, where exon 13 of EML4 is fused to exon 20 of $A L K$ (E13;A20), variant 2, where exon 20 of $E M L 4$ is fused to exon 20 of $A L K$ (E20;A20), and variant 3, where exon 6 of $E M L 4$ is fused to exon 20 of $A L K$ (E6;A20). Two isoforms for $\mathrm{V} 3$ can be generated by alternative splicing, V3a (E6a;A20) and V3b (E6b;A20). ${ }^{19-21}$ Although the portion of EML4 fused to the kinase domain of ALK can vary, all the variants contain the amino-terminal coiled-coil domain within EML4, which is necessary for the oncogenic activity of EML4/ALK via homodimerization and kinase activation.

Preclinical and clinical data suggest that EML4-ALK variants have different sensitivity to ALK inhibition. ${ }^{22-24}$ In a retrospective analysis, Yoshida et al showed a better efficacy of crizotinib in terms of progression-free survival (PFS) in patients with ALK variant 1 vs nonvariant 1 . Moreover, a greater proportion of patients with $A L K$ variant 1 achieved disease control than those with nonvariant $1 .{ }^{24}$ The $A L K$ gene can have different fusion partners beyond $E M L 4$, including kinesin family member $5 \mathrm{~b}$ (KFIF5), TRK-fused gene (TGF), kinesin light chain $1(K L C 1)$, huntingtin-interacting protein 1 (HIP1) and baculoviral inhibition of apoptosis protein repeat containing 6 (BIRC6). ${ }^{24-30}$

Rearrangements of the $A L K$ gene have been identified in $\sim 3 \%-7 \%$ of NSCLC and are more frequent in younger patients, with adenocarcinoma histology with signet-ring cell pattern and a never or light smoking history. ${ }^{31,32} A L K$ rearrangements generally occur independently of other driver mutations, including EGFR and KRAS mutations, ${ }^{33}$ although concomitant actionable mutations have been described. 
Several methods are currently available to detect $A L K$ rearrangements in NSCLC clinical samples. ${ }^{34-37}$ The break-apart fluorescence in situ hybridization was the first diagnostic test to be approved by the US Food and Drug Administration (FDA) as a diagnostic gold standard for screening of $A L K$-rearranged NSCLC. Other methods include immunohistochemistry, demonstrating high sensitivity, specificity and comparable results with fluorescence in situ hybridization, although it is less expensive and time consuming, realtime polymerase chain reaction, and novel techniques such as hybrid capture-based next-generation sequencing and Nanostring technology.

\section{Current treatment of $A L K$-rearranged NSCLC}

Crizotinib, an oral small-molecule TKI of ALK, c-MET and ROS1 kinases, ${ }^{38,39}$ was the first targeted agent to be approved in 2011 for pretreated, $A L K$-rearranged NSCLC, based on pronounced activity seen in early Phase I and II studies, with the objective response rates (ORRs) ranging from 57\% to $61 \%$ and median PFS from 8.1 to 9.7 months. ${ }^{40-42}$ Subsequent Phase III trials demonstrated the superiority, in terms of PFS and ORR, of crizotinib compared to standard chemotherapy in previously treated (PROFILE 1007 study) ${ }^{43}$ and previously untreated (PROFILE 1014 study) ${ }^{44}$ patients with advanced $A L K$-positive NSCLC, thus establishing it as a standard of care for this subset of patients also in the first-line setting. In both studies, crizotinib was generally well tolerated and resulted in greater improvement in quality of life (QoL) compared to chemotherapy. ${ }^{43,44}$

However, despite marked and durable initial responses to crizotinib, most patients develop progressive disease, generally within 1-2 years of starting therapy, similar to what happens with other targeted therapies. ${ }^{45}$ The central nervous system (CNS) is one of the most common sites of relapse. This can be explained by pharmacokinetic (PK) limitations rather than a biologic resistance. Crizotinib is indeed a known substrate of P-glycoprotein (P-gp), a drug efflux pump expressed in the capillary epithelial cells of the blood-brain barrier (BBB) that limits accumulation of the drug in the CNS. ${ }^{46-48}$ Molecular mechanisms leading to crizotinib resistance have been commonly classified as on-target genetic alterations (secondary point mutations within the $A L K$-TK domain and $A L K$ copy number alterations) and off-target mechanisms, such as activation of "bypass" signaling pathways and others (eg, epithelial-mesenchymal transition). ${ }^{49-51}$

The initial report of two secondary mutations (L1196M and $\mathrm{C} 1156 \mathrm{Y}$ ) came from the molecular analysis of postprogression tissue biopsy from a patient who developed resistance to crizotinib after 5 months. ${ }^{52}$ The gatekeeper mutation L1196M interferes with crizotinib binding through steric hindrance and is analogous to T315I in the $B C R-A B L$ fusion gene and T790M in the EGFR gene conferring resistance to corresponding TKIs. The G1269A mutation is also located in the adenosine triphosphate (ATP)-binding pocket and affects ALK TKI binding. Other secondary resistance mutations have been identified from molecular characterization of postprogression patient specimens (occurring in $\sim 20 \%-40 \%$ of cases) or ALK-resistant cell lines (derived from patients or generated in vitro), including C1156Y, F1174, 1151Tins, L1152R, S1206Y, I1171T, G1202R and D1203N. ${ }^{49-51,53-55}$ Multiple nonoverlapping mutations within the $A L K$ TK domain have been reported, and also, $A L K$ copy number alterations (copy number gain or amplification) can coexist in some cases, thus suggesting a potential heterogeneity of biologic resistance. ${ }^{50,51,56}$ Activation of alternate kinases, including EGFR, KIT, human epidermal growth factor receptor 2 (HER2)/HER3, insulin-like growth factor 1 receptor (IGF-1R), Rous sarcoma oncogene cellular homologue (SRC) and MAPK, leads to ALK-independent growth and resistance to inhibition by crizotinib. ${ }^{49,57-61}$

The evidence of a lack of long-term benefit from crizotinib due to acquisition of resistance has prompted the development of increasingly potent, selective and brain-penetrant ALK inhibitors, with differential spectrum of activity against the most common resistance mutations. Indeed, in initial studies in preclinical models, Ba/F3 cells expressing wild-type EML4-ALK or EML4-ALK with resistance mutations were tested for their sensitivity to a panel of ALK inhibitors. ${ }^{51}$ All of the mutant forms of EML4 ALK were found to be resistant to crizotinib compared with wild-type EML4-ALK and showed different degrees of sensitivity to next-generation ALK inhibitors depending on the type of mutation. For example, G1269A substitution was sensitive to several second-generation ALK inhibitors, whereas G1202R, at the solvent front of the kinase domain of ALK, conferred high-level resistance to almost all the ALK TKIs tested.

Different next-generation ALK inhibitors are currently being evaluated in clinical studies and some have demonstrated pronounced systemic and intracranial activity, in both crizotinib-resistant and crizotinib-naïve $A L K$-rearranged NSCLC. Ceritinib was the first next-generation ALK inhibitor to be approved by the FDA in 2014 for the treatment of patients with $A L K$-positive metastatic NSCLC who have 
progressed on or are intolerant to crizotinib and then by the European Medicines Agency (EMA) in 2015 for advanced $A L K$-positive NSCLC patients previously treated with crizotinib. Among the other next-generation ALK inhibitors, alectinib is currently approved by the FDA and EMA for the treatment of crizotinib-pretreated patients and brigatinib received "Breakthrough Therapy" designation from the FDA for the same indication.

\section{Ceritinib: overcoming crizotinib resistance Design and mechanism of action}

Ceritinib (LDK378; Zykadia ${ }^{\circledR}$, Novartis Pharmaceuticals Corporation) is a potent and selective oral, ATP-competitive TKI of ALK. Ceritinib was derived from the optimization of a first lead compound identified by Novartis, TAE684, ${ }^{62}$ which was shown to be a potent and specific ALK inhibitor, but to have some deficiencies such as the capability to form an extensive number of reactive adducts upon metabolic oxidation, which might create the potential for toxicologic liabilities. This was mainly correlated with the presence of a solubilizing group connected by a nitrogen atom into the central aniline moiety. The modification of this molecule to design novel derivatives was thus performed by reversing the piperidine at the para position of the aniline moiety, replacing the methoxy moiety by an isopropoxy moiety and including a methyl group at the position para to the isopropoxy moiety. ${ }^{63,64}$ Through these modifications, a potent and selective ALK inhibitor, 5-chloro-N2-(2-isopropoxy-5methyl-4-(piperidin-4-yl)phenyl)-N4-(2-(isopropylsulfonyl) phenyl)pyrimidine-2,4-diamine (LDK378, ceritinib), was synthesized (Figure 1). The molecular formula of ceritinib is $\mathrm{C}_{28} \mathrm{H}_{36} \mathrm{ClN}_{5} \mathrm{O}_{3} \mathrm{~S}$ and the molecular weight is $558.14 \mathrm{Da}$. In an enzymatic kinase assay, ceritinib showed higher potency than crizotinib against ALK ( $\mathrm{IC}_{50}$ value of $\left.200 \mathrm{pM}\right)$ and, among a panel of 30 kinases, it also showed biochemical inhibition of IGF-1R, InsR and STK22D. When the cellular kinase profile of ceritinib was assessed in $\mathrm{Ba} / \mathrm{F} 3$ cells, it showed high selectivity against $\mathrm{ALK}\left(\mathrm{IC}_{50}\right.$ of $\left.2.2 \mathrm{nM}\right)$, without inhibiting the activity of other kinases, including IGF-1R. However, inhibition of IGF-1R and other kinases, including InsR and ROS1, can occur at clinically relevant concentrations. ${ }^{65,66}$ In $\mathrm{Ba} / \mathrm{F} 3$ cells transfected with the $N P M-A L K$ fusion gene, ceritinib showed potent antiproliferative activity $\left(\mathrm{IC}_{50}\right.$ value of $26 \mathrm{nM}$ ), with good selectivity over wild-type $\mathrm{Ba} / \mathrm{F} 3$ cells $\left(\mathrm{IC}_{50}>2 \mu \mathrm{M}\right)$ and $\mathrm{Ba} / \mathrm{F} 3$ cells transfected with Tel-InsR gene $\left(\mathrm{IC}_{50}=320 \mathrm{nM}\right) .{ }^{63}$ Ceritinib had an excellent PK profile in rodents and nonrodents, with an oral bioavailability of $>50 \%$.

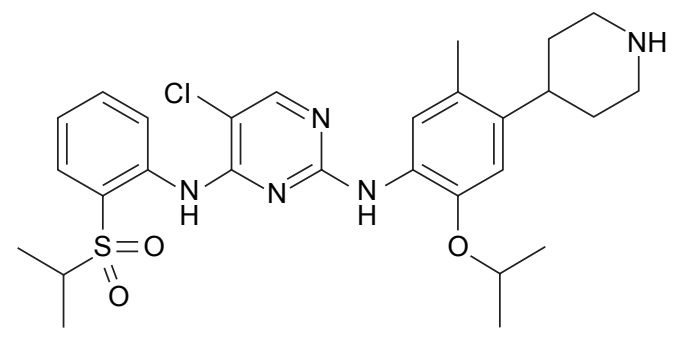

Figure I Chemical structure of ceritinib.

In in vivo studies, the compound displayed significant antitumor activity against rat xenograft models of NPM-ALK anaplastic large cell lymphoma and EML4/ALK-positive NSCLC, causing dose-dependent inhibition of tumor growth, with good tolerability at all dose levels tested ${ }^{63}$ In a tissue distribution study using a rat model, ceritinib crossed the BBB with a brain-to-blood exposure $\left(\mathrm{AUC}_{\text {inf }}\right.$ ) ratio of $\sim 15 \% .{ }^{66}$

\section{Preclinical activity of ceritinib against $A L K$ resistance mutations}

The activity of ceritinib in preclinical models of $A L K$-positive lung cancer with acquired resistance to crizotinib was examined in a landmark study by Friboulet et al. ${ }^{67} \mathrm{In}$ in vitro enzymatic assays, ceritinib was 20 -fold more potent against ALK than crizotinib. Moreover, it was more potent than crizotinib against $A L K$-positive cancer cell lines (H3122 and H228), which led to suppression of ALK phosphorylation, as well as suppression of downstream pathways (such as PI3K/AKT, MAPK/Erk kinase/extracellular signal-regulated kinase and mammalian target of rapamycin) at lower doses than crizotinib (Figure 2). In in vivo studies in treatmentnaïve H2228 xenograft models, ceritinib showed marked and more durable antitumor activity than crizotinib. Ceritinib demonstrated activity against crizotinib-resistant mutations in different cancer cell lines, including two cell lines harboring the L1196M and G1269M mutations that were established from biopsies of $A L K$-positive NSCLC patients who had become resistant to crizotinib, with $\mathrm{GI}_{50}(50 \%$ growth inhibition) values from 6- to 36-fold inferior compared to crizotinib. ${ }^{67}$ In crizotinib-resistant xenograft models derived from cells harboring the L1196M mutation, ceritinib was able to control tumor growth at lower doses compared to crizotinib. Notably, a cell line without any detectable $A L K$ alterations, derived from a biopsy of a patient at the time of progression to crizotinib was highly sensitive to ceritinib, supporting the clinical observation that ceritinib was highly active in crizotinib-resistant cancers with or without $A L K$ secondary mutations. ${ }^{67}$ 


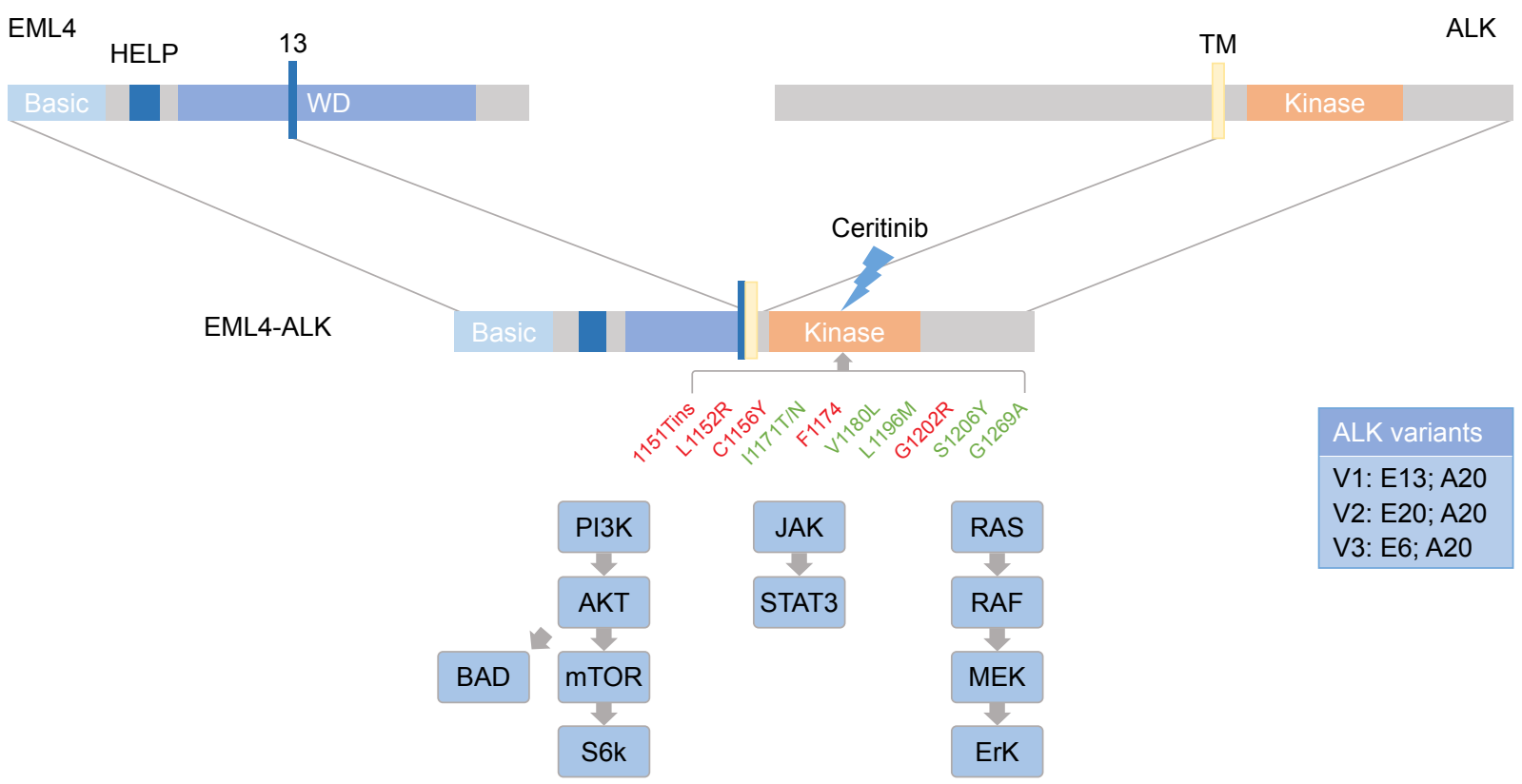

Cell proliferation, survival

Figure 2 Ceritinib is a potent and selective ALK tyrosine kinase inhibitor, with activity against various crizotinib and alectinib resistance mutations (in green). Ceritinibresistant ALK mutations (in red) include GI202R and FII74C/L.

Abbreviations: AKT, protein kinase B; ALK, anaplastic lymphoma kinase; BAD, Bcl-2-associated death promoter; EML4, echinoderm microtubule-associated protein-like 4; ERK, extracellular signal-regulated kinase; HELP, hydrophobic EMAP-like protein; JAK, Janus kinase; MEK, MAPK/Erk kinase; mTOR, mammalian target of rapamycin; PI3K, phosphatidylinositol-4,5-bisphosphate 3-kinase; STAT3, signal transducer and activator of transcription; TM, transmembrane domain; WD, tryptophan-aspartic acid.

The activity of ceritinib against nine additional $A L K$ mutations conferring resistance to crizotinib was tested in $\mathrm{Ba} / \mathrm{F} 3$ cells. Ceritinib potently inhibited the growth of those cells expressing the most common mutations, L1196M, G1269A and also S1206Y and I1171T, but not those with C1156Y, G1202R, 1151Tins, L1152R and F1174C mutations, although it was still more potent than crizotinib against these less-common mutations (Figure 2). In in vivo studies, ceritinib suppressed tumor growth in multiple crizotinibresistant xenograft tumor models, with impressive antitumor activity in I1 171T-resistant models, while less and no activity was observed in the C1156Y - and G1202R-resistant models, respectively. ${ }^{67}$

One main reason explaining the ability of ceritinib to overcome most crizotinib-resistant mutations relies on the distinct molecular structure of these two compounds. Indeed, the presence of G1269A does not prevent ceritinib binding, while, on the other hand, it creates a steric hindrance to the phenyl ring of crizotinib. In the presence of the gatekeeper mutation L1196M, the Cl-moiety of the pyrimidine hingebinding core of ceritinib interacts with methionine (Met). In contrast, crizotinib binding is affected through both steric interference and unfavorable interactions with the 2-amino substituent of the pyridinyl hinge-binding core and the methyl substituent of the alkoxy moiety of crizotinib. ${ }^{67}$ Conversely, ceritinib was less active against the other less-common mutations, including G1202R. The G1202R substitution is located at the solvent front of the ALK domain, abutting the crizotinib-binding site and likely diminishing the binding affinity of all other ALK inhibitors, including ceritinib, to the mutant kinase for steric hindrance, due to the presence of a large, bulky basic residue. ${ }^{51}$

In summary, the next-generation ceritinib was able to overcome various crizotinib-resistant mutations and was potent against several in vitro and in vivo laboratory models of acquired resistance to crizotinib.

\section{Pharmacokinetics}

The PK profile of ceritinib was first evaluated in mice, rats, dogs and monkeys and found to be consistent across all these species. The compound showed good oral bioavailability ( $\geq 55 \%$ ) following a single oral administration and a low plasma clearance compared to liver blood flow, with a high volume of distribution at a steady state $\left(\mathrm{V}_{\mathrm{ss}}\right)$. The time to maximum plasma concentration $\left(\mathrm{T}_{\max }\right)$ occurred late after oral administration, indicating slow oral absorption, with a half-life $\left(\mathrm{T}_{1 / 2}\right)$ ranging from moderate to long (6.2-26 hours).$^{63}$

PK data in humans were reported from patients treated with ceritinib in the first-in-human study. The ASCEND-1 
trial, enrolling patients with advanced cancer harboring genetic alterations in $A L K$ (the majority were advanced NSCLC), included a dose-escalation phase, determining the maximum tolerated dose (MTD), followed by a doseexpansion phase. ${ }^{68} \mathrm{PK}$ analyses were based on data from the dose-escalation phase, in which patients were treated with single daily oral ceritinib at dose levels of 50-750 mg daily, continued in 21-day cycles. Results from these analyses showed that exposure to ceritinib increased with the dose. The maximal plasma concentration $\left(\mathrm{C}_{\max }\right)$ increased slightly more than proportional to the dose, across daily doses ranging from 50 to $750 \mathrm{mg}$. During the 3-day PK evaluation period, after the administration of the first dose of ceritinib at the established MTD (750 mg daily), the $\mathrm{C}_{\max }$ of ceritinib was achieved $\sim 6$ hours later and the mean terminal half-life was $\sim 40$ hours. The mean $( \pm \mathrm{SD})$ area under the plasma concentration-time curve (AUC) over a 24-hour period on day 8 was $16,500 \pm 4,750 \mathrm{ng} / \mathrm{mL} /$ hour. The mean $\mathrm{C}_{\max }$ was $800 \pm 205 \mathrm{ng} / \mathrm{mL}$. After multiple repeated daily oral doses, steady-state levels of ceritinib were achieved by $\sim$ day $15 .{ }^{68}$ The absolute bioavailability of oral ceritinib is not known. ${ }^{66}$ Two studies were conducted in healthy adults to investigate the influence of food on the oral bioavailability of ceritinib: a study with low- or high-fat meals at $500 \mathrm{mg}$ and another study with a light snack at $750 \mathrm{mg} .{ }^{69}$ Higher plasma concentrations for ceritinib were achieved when it was administered under fed conditions (low- and high-fat meals). The $\mathrm{C}_{\max }$ and the AUC from time zero to infinity $\left(\mathrm{AUC}_{0-\infty}\right)$ of ceritinib were increased by $43 \%$ and $58 \%$ after a low-fat meal and by $41 \%$ and $73 \%$ after intake of a high-fat meal, respectively, compared to fasting conditions. ${ }^{69}$ Similar results were observed with oral administration of $750 \mathrm{mg}$ ceritinib with a light snack. These data suggest a higher oral bioavailability and drug exposure with food, and that ceritinib should be taken on an empty stomach. However, a three-arm randomized trial is ongoing to evaluate an alternative way to give ceritinib (lower doses, 450 or $600 \mathrm{mg}$ taken with a low-fat meal), compared to ceritinib $750 \mathrm{mg}$ taken in a fasted state, that may lead to better gastrointestinal tolerability in patients with $A L K$-positive NSCLC while maintaining similar steadystate exposure (NCT02299505). Ceritinib is highly bound to plasma protein (about 97\%), independent of the drug concentration, and displays a preference for red blood cells over plasma (mean blood-to-plasma ratio of 1.35). ${ }^{66}$ The volume of distribution ( $\mathrm{Vd} / \mathrm{F}$ ) after single oral dose (750 mg) of ceritinib is $4230 \mathrm{~L}$. Ceritinib is primarily metabolized by cytochrome P450 family 3 subfamily A (CYP3A) enzymes and is primarily excreted via feces $(92.3 \%$, with $68 \%$ of the dose excreted unchanged, vs $1.3 \%$ via urine).
Compared with crizotinib, according to the FDA prescribing information, ${ }^{66}$ the half-life of ceritinib after a single dose is similar (for ceritinib at $750 \mathrm{mg}$ : 41 hours; for crizotinib at $250 \mathrm{mg}$ : 42 hours) and both ALK inhibitors have a lower clearance at steady state after daily dose administration (ceritinib: $33.2 \mathrm{~L} /$ hour; crizotinib: $60 \mathrm{~L} /$ hour) compared to a single dose (ceritinib: $88.5 \mathrm{~L} /$ hour; crizotinib: $100 \mathrm{~L} /$ hour), indicating nonlinear PK over time.

\section{Drug interactions}

Ceritinib is a substrate of CYP3A, as shown by in vitro studies. ${ }^{66}$ Coadministration with ketoconazole (a strong CYP3A inhibitor) increased ceritinib exposure by 2.9fold, and coadministration with rifampin (a strong CYP3A inducer) decreased ceritinib exposure by $70 \%$ in healthy subjects. ${ }^{66,70}$ Ceritinib may inhibit CYP3A and cytochrome P450 family 2 subfamily C member 9 (CYP2C9) at clinical concentrations. Ceritinib is not a substrate of Breast Cancer Resistance Protein (BCRP), Organic Cation Transporter (OCT1), Organic Anion Transporter (OAT2) or Organic Anion Transporter Polypeptide (OATP1B1) transporter proteins, but is a substrate of efflux transporter P-gp; thus, coadministration with drugs inhibiting P-gp may result in increased levels of ceritinib. ${ }^{66}$ Notably, recent data indicate an important role of the multidrug transporters $\mathrm{p}$-gp/ ATP-binding cassette subfamily B member 1A (ABCB1) and BCRP/ATP-binding cassette subfamily $\mathrm{G}$ member 2 (ABCG2) in regulating accumulation of ceritinib in the brain, thus suggesting a potential combined approach with inhibitors of these proteins and ceritinib to improve treatment of brain metastases or in those tumors overexpressing ABCB1 and/or ABCG2. ${ }^{71}$ Ceritinib demonstrates poor solubility as $\mathrm{pH}$ increases in vitro, thus its bioavailability may be altered by concomitant gastric acid reducing agent administration, although there are no studies specifically designed to evaluate this association. ${ }^{66}$

\section{Clinical development Phase I and II studies}

Ceritinib was tested in a Phase I study, the ASCEND-1, which enrolled patients with advanced cancers with genetic alterations in $A L K$, including $A L K$-rearranged NSCLC (including patients who had previously received an ALK inhibitor). ${ }^{68}$ In the dose-escalation phase of the study, ceritinib was administered as a single oral daily dose starting from $50 \mathrm{mg}$, on the basis of preclinical safety data. Based on the occurrence of dose-limiting toxicities, including diarrhea, vomiting, dehydration, elevated aminotransferase levels and hypophosphatemia, the MTD of 
ceritinib was defined to be $750 \mathrm{mg}$ once daily, which was the dose assessed in the dose-expansion phase. The assessment of antitumor activity of ceritinib was a key secondary objective of this study. Ceritinib demonstrated significant clinical activity in advanced, $A L K$-rearranged NSCLC patients, with an ORR of 58\% (95\% CI: 48-67) among those patients who received at least $400 \mathrm{mg}$ of ceritinib per day (Table 1). ${ }^{68}$ The ORR was $62 \%$ in ALK inhibitor-naive patients and $56 \%$ in crizotinib-pretreated patients, including patients with untreated brain CNS lesions after crizotinib progression. Some responses were dramatic and rapid. The median duration of response was 8.2 months. Overall median PFS was 7 months (95\% CI: 5.6-9.5), 6.9 months in the subgroup of ALK inhibitor-pretreated patients and 10.4 months in patients who had not received crizotinib previously. Adverse events (AEs) were more gastrointestinal, of grade 1 or 2 (Table 2). Of interest, responses to ceritinib were observed regardless of the presence of $A L K$ resistance mutations detected in tumor tissues from rebiopsy taken at the time of crizotinib resistance before study entry, thus

Table I Summary of data from selected clinical trials of ceritinib

\begin{tabular}{|c|c|c|c|c|c|c|c|}
\hline Study name & Phase & \begin{tabular}{|l} 
Patient \\
population
\end{tabular} & Study treatment & ORR & \begin{tabular}{|l|} 
Intracranial \\
ORR $(\%)$ \\
(n of patients)
\end{tabular} & PFS & OS \\
\hline \multirow[t]{2}{*}{ ASCEND- $1^{68}$} & \multirow[t]{2}{*}{$I$} & \multirow[t]{2}{*}{$\begin{array}{l}\text { Advanced cancers } \\
\text { with ALK alterations } \\
\text { (ALK-rearranged } \\
\text { NSCLC, } n=122 \text { ) }\end{array}$} & \multirow[t]{2}{*}{\begin{tabular}{|l} 
Ceritinib \\
(50-750 mg once \\
daily)
\end{tabular}} & $\begin{array}{l}58 \% \text { (95\% Cl: } \\
48-67): 56 \% \\
\text { in crizotinib- } \\
\text { pretreated } \\
\text { patients* }\end{array}$ & \multirow[t]{2}{*}{-} & $\begin{array}{l}7 \text { months } \\
(95 \% \text { Cl: } 5.6-9.5) \text { : } \\
6.9 \text { months } \\
\text { in crizotinib- } \\
\text { pretreated } \\
\text { patients }\end{array}$ & \multirow[t]{2}{*}{-} \\
\hline & & & & \begin{tabular}{|l|}
$62 \%$ in crizotinib- \\
naïve patients
\end{tabular} & & $\begin{array}{l}\text { NR in crizotinib- } \\
\text { naïve patients }\end{array}$ & \\
\hline \multirow[t]{2}{*}{$\begin{array}{l}\text { ASCEND-I } \\
\text { (updated } \\
\text { analysis) }\end{array}$} & \multirow[t]{2}{*}{ I } & $\begin{array}{l}\text { ALK-rearranged } \\
\text { NSCLC: ALK inhibitor } \\
\text { naïve }(n=39)\end{array}$ & \multirow[t]{2}{*}{$\begin{array}{l}\text { Ceritinib } \\
(750 \mathrm{mg} / \text { day })\end{array}$} & $\begin{array}{l}72 \%(95 \% \mathrm{Cl}: \\
6 \mathrm{I}-82)\end{array}$ & $\begin{array}{l}63 \%(95 \% \mathrm{Cl}: \\
25-92)\end{array}$ & $\begin{array}{l}18.4 \text { months } \\
(95 \% \mathrm{Cl}: \\
\text { II.I-NE) } \\
\end{array}$ & $\begin{array}{l}\text { NR (95\% Cl: } \\
19 \cdot 6-N E)\end{array}$ \\
\hline & & $\begin{array}{l}\text { ALK inhibitor pretreated } \\
(n=83)\end{array}$ & & $\begin{array}{l}56 \%(95 \% \mathrm{Cl}: \\
49-64)\end{array}$ & $\begin{array}{l}36 \%(95 \% \mathrm{Cl}: \\
19-56)\end{array}$ & $\begin{array}{l}6.9 \text { months } \\
(95 \% \text { Cl: } 5.6-8.7)\end{array}$ & $\begin{array}{l}\text { I6.7 months } \\
(95 \% \mathrm{Cl}: \\
\text { I4.8-NE) }\end{array}$ \\
\hline ASCEND-2 ${ }^{74}$ & II & $\begin{array}{l}\text { Chemotherapy } \\
\text { (including platinum } \\
\text { doublet) and crizotinib- } \\
\text { pretreated, ALK- } \\
\text { rearranged NSCLC } \\
(\mathrm{n}=\mid 40)\end{array}$ & $\begin{array}{l}\text { Ceritinib } \\
(750 \mathrm{mg} / \text { day })\end{array}$ & $\begin{array}{l}38.6 \%(95 \% \mathrm{Cl}: \\
30.5-47.2)\end{array}$ & $\begin{array}{l}45 \%(95 \% \mathrm{Cl}: \\
23.1 \%-68.5 \%)\end{array}$ & $\begin{array}{l}5.7 \text { months } \\
(95 \% \mathrm{Cl}: 5.4-7.6)\end{array}$ & $\begin{array}{l}\text { I4.9 months } \\
(95 \% \mathrm{Cl}: \\
\text { I3.5-NE) }\end{array}$ \\
\hline \multirow[t]{5}{*}{$\begin{array}{l}\text { ASCEND-3 } \\
(\text { FUP }>2 \text { years })^{75}\end{array}$} & \multirow[t]{5}{*}{ II } & $\begin{array}{l}\text { ALK TKI-naïve, } \\
\text { chemotherapy-pretreated, }\end{array}$ & \multirow[t]{5}{*}{$\begin{array}{l}\text { Ceritinib } \\
(750 \mathrm{mg} / \text { day })\end{array}$} & \begin{tabular}{|l|}
$67.7 \%(95 \% \mathrm{Cl}$ \\
$58.8-75.9)$ \\
\end{tabular} & \multirow[t]{5}{*}{$\begin{array}{l}61.5 \%(95 \% \mathrm{Cl}: \\
31.6-86.1)\end{array}$} & \multirow{5}{*}{$\begin{array}{l}\text { I6.6 months } \\
(95 \% \mathrm{Cl}: \\
\text { II-22.I) }\end{array}$} & \multirow{5}{*}{$\begin{array}{l}\text { Estimated } \\
24 \text { months: } \\
77.5 \% \\
(95 \% \mathrm{Cl}: \\
58.0-75.2)\end{array}$} \\
\hline & & ALK-rearranged NSCLC & & \multirow{3}{*}{$\begin{array}{l}57.1 \%(95 \% \mathrm{Cl}: \\
42.2-71.2)\end{array}$} & & & \\
\hline & & All patients $(n=124)$ & & & & & \\
\hline & & $\begin{array}{l}\text { - Patients with BM } \\
(\mathrm{n}=49)\end{array}$ & & & & & \\
\hline & & $\begin{array}{l}\text { - Patients without BM } \\
(\mathrm{n}=75)\end{array}$ & & \begin{tabular}{|l|}
$74.7 \%(95 \% \mathrm{Cl}:$ \\
$63.3-84.0)$ \\
\end{tabular} & & & \\
\hline \multirow[t]{2}{*}{ ASCEND-4 ${ }^{76}$} & \multirow[t]{2}{*}{ III } & \multirow{2}{*}{$\begin{array}{l}\text { Treatment-naïve (no prior } \\
\text { chemotherapy or ALK } \\
\text { inhibitor), ALK-rearranged } \\
\text { NSCLC }(n=376)\end{array}$} & Ceritinib & \begin{tabular}{|l}
$72.5 \%$ (95\% Cl: \\
$65.5-78.7)$ \\
\end{tabular} & \begin{tabular}{|l|}
$72.7 \%(95 \% \mathrm{Cl}:$ \\
$49.8-89.3)$ \\
\end{tabular} & 16.6 months & NE \\
\hline & & & \begin{tabular}{|l|} 
Cisplatin \\
$75 \mathrm{mg} / \mathrm{m}^{2}$ or \\
carboplatin AUC \\
$5-6 /$ pemetrexed \\
$500 \mathrm{mg} / \mathrm{m}^{2}$ \\
\end{tabular} & $\begin{array}{l}26.7 \%(95 \% \mathrm{Cl}: \\
20.5-33.7)\end{array}$ & \begin{tabular}{|l|}
$27.3 \%(95 \% \mathrm{Cl}$ \\
$10.7-50.2)$
\end{tabular} & $\begin{array}{l}\text { 8.I months } \\
(\mathrm{HR} 0.55,95 \% \\
\mathrm{Cl}: 0.42-0.73)\end{array}$ & $\begin{array}{l}26.2 \text { months } \\
\text { (HR 0.73, } \\
95 \% \mathrm{Cl}: \\
0.50-1.08)\end{array}$ \\
\hline \multirow[t]{3}{*}{ ASCEND- $5^{77}$} & \multirow[t]{3}{*}{ III } & \multirow{3}{*}{$\begin{array}{l}\text { Chemotherapy (including } \\
\text { platinum doublet) and } \\
\text { crizotinib-pretreated, } \\
\text { ALK-rearranged } \\
\text { NSCLC }(n=23 \mathrm{I})\end{array}$} & Ceritinib & $39.1 \%(95 \% \mathrm{Cl}:$ & \multirow[t]{3}{*}{-} & 5.4 months & \multirow[t]{2}{*}{ I8.I months } \\
\hline & & & \begin{tabular}{|l|} 
Pemetrexed 500 \\
$\mathrm{mg} / \mathrm{m}^{2}$ or docetaxel
\end{tabular} & $30.2-48.7)$ & & & \\
\hline & & & $\begin{array}{l}75 \mathrm{mg} / \mathrm{m}^{2} \text { (crossover } \\
\text { to ceritinib at PD) }\end{array}$ & $\begin{array}{l}6.9 \%(95 \% \mathrm{Cl} \\
3-13.1)\end{array}$ & & $\begin{array}{l}\text { I.6 months } \\
(\mathrm{HR} 0.49,95 \% \mathrm{Cl} \\
0.36-0.67)\end{array}$ & $\begin{array}{l}20.1 \text { months } \\
(\mathrm{HR} \text { I.0,95\% } \\
\mathrm{Cl} 0.67-\mathrm{I} .49)\end{array}$ \\
\hline
\end{tabular}

Note: *II4 NSCLC patients who received ceritinib at least $400 \mathrm{mg}$ daily.

Abbreviations: ALK, anaplastic lymphoma kinase; AUC, area under the curve; BM, brain metastases; Cl, confidence interval; HR, hazard ratio; NA, not assessed; NE, not estimable; NR, not reached; NSCLC, non-small cell lung cancer; ORR, objective response rate; OS, overall survival; PD, progression of disease; PFS, progression-free survival; TKI, tyrosine kinase inhibitor. 
Table 2 Most common adverse events from clinical trials of ceritinib

\begin{tabular}{|c|c|c|}
\hline Study name & All grades & Grade $\geq 3$ ( $\geq 5 \%$ of patients) \\
\hline ASCEND- I $^{72}$ & $\begin{array}{l}\text { Diarrhea }(86 \%) \text {, nausea }(83 \%) \text {, vomiting }(61 \%) \text {, ALT increased }(45 \%) \text {, ALT } \\
\text { increased }(45 \%) \text {, fatigue }(43 \%) \text {, abdominal pain }(38 \%) \text {, decreased appetite } \\
(38 \%) \text {, AST increased }(33 \%) \text {, constipation }(30 \%) \text {, cough }(29 \%) \text {, dyspnea } \\
(25 \%) \text {, headache }(21 \%)\end{array}$ & $\begin{array}{l}\text { ALT increased (30\%), AST increased ( } 10 \%) \text {, diarrhea } \\
(6 \%) \text {, nausea }(6 \%) \text {, lipase increased }(6 \%) \text {, hyperglycemia } \\
(6 \%) \text {, anemia }(5 \%) \text {, pneumonia }(5 \%) \text {, fatigue }(5 \%) \text {, } \\
\text { blood alkaline phosphatase increased }(5 \%)\end{array}$ \\
\hline ASCEND-2 $2^{74}$ & $\begin{array}{l}\text { Nausea }(81.4 \%) \text {, diarrhea }(80 \%) \text {, vomiting }(62.9 \%) \text {, ALT increased }(43.6 \%) \text {, } \\
\text { decreased appetite }(40.7 \%) \text {, fatigue }(36.4 \%) \text {, weight decreased }(34.3 \%) \text {, AST } \\
\text { increased }(32.1 \%) \text {, abdominal pain }(31.4 \%) \text {, constipation }(28.6 \%) \text {, cough } \\
(21.4 \%) \text {, dyspnea }(20.7 \%) \text {, pyrexia }(20.7 \%)\end{array}$ & $\begin{array}{l}\text { ALT increased ( } 17.1 \%), \gamma \text {-GT increased }(12.1 \%) \text {, } \\
\text { diarrhea }(6.4 \%) \text {, nausea }(6.4 \%) \text {, fatigue }(6.4 \%) \text {, AST } \\
\text { increased }(5 \%) \text {, dyspnea }(5.7 \%)\end{array}$ \\
\hline ASCEND-375 & $\begin{array}{l}\text { Diarrhea }(85.5 \%) \text {, nausea }(77.4 \%) \text {, vomiting }(71.8 \%) \text {, decreased appetite } \\
(53.2 \%) \text {, ALT increased }(50 \%) \text {, AST increased }(42.7 \%) \text {, fatigue }(37.9 \%) \text {, } \\
\text { abdominal pain }(37.1 \%) \text {, weight decreased }(34.7 \%), \gamma-G T \text { increased }(27.4 \%) \text {, } \\
\text { constipation }(25 \%) \text {, blood creatinine increased }(24.2 \%) \text {, dyspnea }(24.2 \%) \text {, } \\
\text { blood ALP increased }(23.4 \%) \text {, back pain }(22.6 \%) \text {, cough }(21.8 \%) \text {, headache } \\
(21 \%) \text {, rash }(20.2 \%)\end{array}$ & $\begin{array}{l}\text { ALT increased }(21 \%), \gamma-\text { GT increased }(19.4 \%) \text {, AST } \\
\text { increased }(9.7 \%) \text {, blood ALP increased }(7.3 \%) \text {, fatigue } \\
(8.1 \%) \text {, nausea }(6.5 \%) \text {, vomiting }(6.5 \%)\end{array}$ \\
\hline ASCEND $-4^{76}$ & $\begin{array}{l}\text { Diarrhea (85\%), nausea }(69 \%) \text {, vomiting }(66 \%) \text {, ALT increased }(60 \%) \text {, AST } \\
\text { increased }(53 \%), \gamma \text {-GT increased }(37 \%) \text {, decreased appetite }(34 \%) \text {, ALP } \\
\text { increased }(29 \%) \text {, fatigue }(29 \%) \text {, abdominal pain }(25 \%) \text {, cough }(24 \%) \text {, weight } \\
\text { decreased }(24 \%) \text {, blood creatinine increased }(22 \%) \text {, upper abdominal pain } \\
(21 \%) \text {, noncardiac chest pain }(20 \%)\end{array}$ & $\begin{array}{l}\text { ALT increased ( } 3 \text { I \%), } \gamma \text {-GT increased ( } 29 \%) \text {, AST } \\
\text { increased (I } 7 \%) \text {, ALP increased ( } 7 \%) \text {, diarrhea ( } 5 \%) \text {, } \\
\text { vomiting (5\%) }\end{array}$ \\
\hline ASCEND- $5^{77}$ & $\begin{array}{l}\text { Diarrhea }(72.2 \%) \text {, nausea }(66.1 \%) \text {, vomiting }(52.2 \%) \text {, ALT increased } \\
(42.6 \%) \text {, decreased appetite }(41.7 \%) \text {, AST increased }(36.5 \%) \text {, weight } \\
\text { decreased }(29.6 \%) \text {, fatigue }(27 \%) \text {, asthenia }(22.6 \%) \text {, blood ALP increased } \\
(22.6 \%), \gamma-G T \text { increased }(22.6 \%) \text {, abdominal pain }(21.7 \%) \text {, back pain }(21.7 \%)\end{array}$ & $\begin{array}{l}\text { ALT increased }(20.9 \%), \gamma-G T \text { increased }(20.9 \%) \text {, AST } \\
\text { increased }(13.9 \%) \text {, nausea }(7.8 \%) \text {, vomiting }(7.8 \%) \text {, } \\
\text { ALP increased }(6.1 \%) \text {, fatigue }(5.2 \%) \text {, asthenia }(5.2 \%) \text {, } \\
\text { diarrhea }(4.3 \%)\end{array}$ \\
\hline
\end{tabular}

Abbreviations: $\gamma$-GT, $\gamma$-glutamyl transferase; ALP, alkaline phosphatase; ALT, alanine aminotrasferase; AST, aspartate aminotransferase.

confirming results from preclinical studies and suggesting that cells can become resistant due to incomplete inhibition of ALK by crizotinib at clinically relevant concentrations, so a more potent and structurally distinct ALK inhibitor can overcome this resistance, or even that ceritinib may have a broader range of activity against unknown resistance genetic alterations. Based on this study, in April 2014, the FDA granted accelerated approval to ceritinib for the treatment of patients with $A L K$-positive metastatic NSCLC with disease progression or who are intolerant to crizotinib. In February 2015, the EMA Committee for Medicinal Products for Human Use adopted a positive opinion, recommending the granting of a conditional marketing authorization for ceritinib in patients with advanced $A L K$-positive NSCLC previously treated with crizotinib. An updated analysis of the ASCEND-1, including all $A L K$-rearranged NSCLC patients $(n=246)$ who received oral ceritinib at $750 \mathrm{mg} /$ day in the dose-escalation and -expansion phases, has been recently reported. ${ }^{72}$ After a median follow-up of 11 months, ceritinib confirmed its high activity and resulted in clinically meaningful and durable antitumor responses in ALK inhibitor-naïve patients (median duration of response [DOR] was 17.0 months and PFS was 18.4 months) and in ALK inhibitor-pretreated patients (median DOR was 8.3 months and PFS was 6.9 months). ${ }^{72}$ All those patients with tumors harboring common $A L K$ resistance mutations, including E1129V, L1196M, C1156Y, I1171T and F1174V, had partial responses with ceritinib, while a patient with G1202R did not respond. ${ }^{73}$ Ceritinib also showed significant intracranial responses, as demonstrated in a retrospective analysis. Indeed, of 36 patients with asymptomatic measurable brain metastases at baseline, $63 \%$ (95\% CI: 25-92) of crizotinibnaïve patients achieved an intracranial response, as did $36 \%$ (19-56) of crizotinib-pretreated patients (Table 1). ${ }^{73}$ The median time to intracranial response was similar to that of whole-body response. Responses were observed in more than half of patients who had received prior brain radiotherapy, indicating a $\mathrm{BBB}$ penetration of this highly potent ALK inhibitor.

In the open-label, multicenter, Phase II study, ASCEND-2, patients with advanced $A L K$-rearranged NSCLC, previously treated with at least one platinum-based chemotherapy and who experienced progression during crizotinib treatment as their last prior therapy, received oral ceritinib at a standard dose of $750 \mathrm{mg}$ daily. ${ }^{74}$ Patients with asymptomatic or neurologically stable baseline brain metastases were included. The results from this study were generally consistent with those reported for the ASCEND-1 study. The ORR was 38.6\%, 
with a disease control rate (DCR) of $77.1 \%$. The responses were rapid (time to response [TTR] 1.8 months) and durable (median DOR 9.7 months). The median PFS and OS were 5.7 and 14.9 months, respectively (Table 1). Among 20 patients who had baseline measurable brain lesions, an intracranial DCR of $80 \%$ was achieved. Overall, the safety profile was consistent with that of ASCEND-1 and no new or unexpected serious AEs (SAEs) were reported (Table 2). ${ }^{74} \mathrm{~A}$ trend toward improved lung cancer symptoms was observed. However, patients reported worse gastrointestinal symptoms, compared to baseline, throughout the treatment, but the global QoL score was maintained during treatment.

In the ASCEND-3, a single-arm, open-label, multicenter Phase II study, ceritinib was assessed in advanced or metastatic ALK+ NSCLC patients, who were chemotherapy naïve or had received up to three lines of chemotherapy and no prior ALK-TKIs treatment. Long-term follow-up results ( $>2$ years) have been recently presented. ${ }^{75}$ A total of 124 patients were enrolled; $40 \%$ had brain metastases at baseline, of whom more than a half had received prior brain radiotherapy. The ORR assessed by blinded independent review committee was $63.7 \%$ (95\% CI: 54.6\%-72.2\%), with a median PFS of 18.4 months (Table 1). Median OS was not reached at data cutoff, and the estimated 24-month OS rate was $67.5 \%$. Intracranial response rate in those patients with measurable brain metastases at baseline (13 patients) was $61.5 \%$, including one complete response, with an intracranial DCR of $76.9 \%$. The AEs were consistent with the known safety profile of ceritinib (Table 2). Approximately $80 \%$ of patients had dose interruptions or adjustments due to AEs. Updated patient-reported outcome (PRO) results were consistent with the primary analysis and showed improvement of symptoms from baseline and the QoL was maintained.

\section{Phase III studies}

Two randomized Phase III trials compared ceritinib vs standard chemotherapy in the first-line (ASCEND-4) ${ }^{76}$ or secondline (ASCEND-5) setting. ${ }^{74}$ The primary endpoint of both studies was PFS. The ASCEND-4 trial included 376 patients with previously untreated, $A L K$-positive, advanced NSCLC, who were randomly assigned to receive ceritinib $750 \mathrm{mg}$ /day or pemetrexed-platinum chemotherapy, followed by maintenance pemetrexed. ${ }^{76}$ Ceritinib treatment significantly improved median PFS compared to chemotherapy, with a risk reduction of $45 \%$ in PFS (16.6 vs 8.1 months for ceritinib and chemotherapy, respectively; hazard ratio [HR] 0.55, 95\%
CI: $0.42-0.73 ; P<0.00001)$, as shown in Table 1. Ceritinib was also associated with improved median PFS compared to chemotherapy both in the subgroup of patients without brain metastases (26.3 vs 8.3 months, HR 0.48, 95\% CI: 0.33-0.69) and with brain metastases (10.7 vs 6.7 months, HR 0.70 , 95\% CI: 0.44-1.12). In addition, significantly higher and durable responses were attained with ceritinib compared to chemotherapy (ORR and DOR: $72.7 \%$ and 23.9 months vs $27.3 \%$ and 16.6 months, respectively), as shown in Table 1. In patients with measurable brain metastases at baseline, ceritinib showed a high overall intracranial response rate of $72.7 \%$, an intracranial clinical benefit rate of $86.4 \%$ at 24 weeks and a median duration of intracranial response of 16.6 months. The median OS was not reached in the ceritinib group and was 26.2 months in the control group. AEs on ceritinib were frequent, but generally considered manageable and acceptable, and only $5.3 \%$ patients discontinued treatment due to AEs suspected to be drug related (Table 2). Ceritinib led to significant improvements in QoL and improved lung cancer symptom scores, compared to chemotherapy. These data strongly favor ceritinib vs standard chemotherapy as firsttherapeutic approach in $A L K$-rearranged NSCLC patients. However, given the superiority of crizotinib compared with platinum/pemetrexed chemotherapy in the first-line setting of $A L K$-positive NSCLC, currently, chemotherapy should not represent the optimal control arm anymore, and current trials are ongoing to compare head-to-head next-generation ALK inhibitors and crizotinib.

In the open-label, randomized, Phase III ASCEND-5 study, ceritinib was compared with chemotherapy (docetaxel or pemetrexed) in locally advanced or metastatic, $A L K$-rearranged NSCLC patients who had received previous crizotinib (any time prior to enrollment) and chemotherapy (including a platinum doublet) ${ }^{77}$ Patients who discontinued chemotherapy due to disease progression could crossover to ceritinib. Results were recently presented and showed that median PFS, as assessed by blinded independent review committee, was significantly improved with ceritinib compared to chemotherapy (5.4 vs 1.6 months; HR 0.49, 95\% CI: 0.36-0.67; $P<0.001)$. The improvement in PFS was robust, demonstrating consistency across a number of subgroups, and clinical benefit was further supported by ORR (39.1\% vs $6.9 \%$ ) and DCR (76.5\% vs $36.2 \%)$, as shown in Table 1. Furthermore, there was a trend toward a reduction in many patient-reported lung cancer-related symptoms with ceritinib. ${ }^{77}$ Although the OS data were immature, there seemed to be no improvement with ceritinib, probably 
because of the high number of patients crossed over to ceritinib after progression. The incidence and the type of AEs were consistent with those reported in Phase I and Phase II study (Table 2).

\section{Intracranial activity of next-generation ALK inhibitors in crizotinib-resistant NSCLC patients}

A significant portion, reported as $26 \%$ of patients enrolled on PROFILE 1014, of patients with $A L K$-positive NSCLC present with brain metastasis at baseline. ${ }^{44,49}$ Moreover, CNS is recognized to be one of the most common sites of progression during crizotinib. In a retrospective, pooled analysis from the PROFILE 1005 and 1007 trials, among patients with asymptomatic untreated brain metastases who received crizotinib, the median time to intracranial progression was 7 months, compared with a 12.5-month median time to systemic progression. Moreover, the CNS was a site of progression in $70 \%$ of patients with known brain metastases during crizotinib treatment and $20 \%$ of those without brain metastases at study entry had progression in CNS on crizotinib. ${ }^{49,78}$ As we have commented, the predisposition toward CNS progression during crizotinib is attributable to poor accumulation of the drug into the CNS. ${ }^{46-49}$

Next-generation ALK inhibitors have been developed to be more potent and with improved BBB penetration compared to crizotinib, and this has resulted in significant intracranial activity and CNS disease control. In Phase I and Phase II studies in crizotinib-resistant patients with measurable lesions at baseline, the reported ORR and intracranial DCR were $36 \%-45 \%$ and $80 \%$ for ceritinib, ${ }^{72,74} 64 \%$ and $90 \%$ for alectinib (in the pooled analysis of NP28761 and NP28673 studies) $)^{79}$ and 53\% and $86 \%$ for brigantinib, respectively (Table 1). ${ }^{80}$ In contrast to crizotinib and ceritinib, alectinib is not a P-gp substrate and can achieve higher CNS levels compared to these compounds, as demonstrated in preclinical models and also in clinical studies. ${ }^{71,81}$ Also, preliminary clinical results with brigatinib confirm its significant CNS activity demonstrated in preclinical studies in an orthotopic mouse brain tumor model. ${ }^{82}$ Another potent, next-generation ALK and ROS1 inhibitor, lorlatinib, has shown preclinical and clinical intracranial activity. ${ }^{83-85}$ Indeed, lorlatinib induced regression of EML4-ALK-driven brain metastases, leading to prolonged survival in vivo. In an ongoing Phase I study, lorlatinib was associated with an intracranial ORR on target lesions of $42 \%$ in $A L K$-positive patients and an impressive intracranial ORR of $80 \%$ in ROS1-positive patients. ${ }^{85}$
The ASCEND-7 is a multicenter, open-label, Phase II ongoing study to evaluate prospectively the efficacy and safety of ceritinib (administered orally once daily at a dose of $750 \mathrm{mg}$ ) in patients with $A L K$-positive NSCLC, metastatic to the brain without evidence of leptomeningeal carcinomatosis (previously treated or untreated with radiation to the brain and with or without prior exposure to crizotinib), and in patients with leptomeningeal carcinomatosis with or without evidence of active lesion at the baseline gadolinium-enhanced brain MRI (previous treatment with ALK inhibitors other than crizotinib is not allowed in the latter arm). Overall response rate is the primary outcome. Secondary outcome measures include time to intracranial tumor response, PFS and OS (NCT02336451).

\section{Safety and tolerability}

Ceritinib was well tolerated in all clinical studies, with most AEs of grade 1 and 2 and very rare events of grade $\geq 3$ (Table 2). In the dose-escalation phase of the ASCEND-1, in which ceritinib was administered at dose levels of 50-750 mg daily, dose-limiting toxicities occurred in six patients at doses of $\geq 400 \mathrm{mg}$ and included nausea and vomiting at $750 \mathrm{mg} /$ daily, diarrhea at a daily dose $\geq 600 \mathrm{mg}$, dehydration at $600 \mathrm{mg}$ daily, increase in alanine aminotransferase (ALT) and hypophosphatemia at $400 \mathrm{mg}$ daily. ${ }^{68}$ The most common AEs of any grade occurring among the 130 patients included in the study were nausea (82\%), diarrhea (47\%), vomiting (65\%), fatigue (47\%) and increased ALT levels (35\%). The most common AEs of grade 3 or 4 related to the study drug were increased ALT levels (21\%), increased aspartate aminotransferase levels (11\%), diarrhea (7\%) and increased lipase levels (7\%); other less-common grade 3 or 4 toxicities included hypophosphatemia (3\%), elevated amylase level and hyperglycemia (both $2 \%$ ). No treatment-related deaths were reported. All toxicities were reversible on discontinuation of treatment. However, a high percentage of patients required dose reduction $(51 \%$ of patients treated across all dose levels and $62 \%$ of patients treated with $750 \mathrm{mg}$ daily). Four cases of interstitial lung disease and one case of asymptomatic grade 3 prolongation of the corrected QT interval were reported, possibly related to ceritinib therapy. In $8(6 \%)$ of 130 patients, ceritinib treatment was permanently discontinued. In the update analysis of ASCEND-1, including patients with $A L K$-rearranged NSCLC who received ceritinib at $750 \mathrm{mg} /$ day, $97 \%$ of patients had AEs suspected to be related to treatment. ${ }^{72}$ The most common AEs of grade 1-2 were gastrointestinal disorders (diarrhea, nausea and vomiting), which occurred 
in $99 \%$ of patients and were manageable through use of concomitant medication and dose modifications. The most common grade 3-4 AEs (nonlaboratory and laboratory) were diarrhea and nausea (both 6\%), increased ALT (30\%) and aspartate aminotransferase (10\%), increased lipase (7\%) and hyperglycemia ( $6 \% ; 2 \%$ was reported as an SAE), as shown in Table 2. Grade 3 or 4 treatment-related AEs and SAEs of any grade were reported in $51 \%$ and $12 \%$ of patients, respectively. Interstitial lung disease or pneumonitis was reported in nine (4\%) patients (grade $\geq 3$ in eight patients, including one leading to death), and no case of prolongation of the corrected QT interval $(>500 \mathrm{~ms})$ was observed. Twenty-six (11\%) patients discontinued treatment due to AEs.

Safety analyses from the ASCEND-2 were consistent with those of ASCEND-1, with no new or unexpected SAE. ${ }^{74}$ Gastrointestinal disorders, mainly of grade 1 or 2 (nausea $81.4 \%$, diarrhea $80 \%$ and vomiting $62.9 \%$ ), were the most prevalent AEs. Overall, grade $\geq 3$ AEs were reported in $71.4 \%$ of all patients, and in $45.7 \%$ of patients, they were suspected to be drug related (Table 2). Among these, the ALT and $\gamma$-GT increase occurred in $15.7 \%$ and $9.3 \%$ of patients, respectively. Prolongation of QTc and pneumonitis occurred at any grade in $1.4 \%$ and $7.9 \%$ of patients, respectively, and grade $\geq 3$ of these AEs each occurred in one patient. Drug-related SAEs were reported in $17.1 \%$ of patients. Only $7.9 \%$ of patients discontinued treatment due to an AE. ${ }^{74}$ PROs showed a trend toward improved symptom burden and QoL was maintained during treatment. Also, in the ASCEND-3 trial, ceritinib was associated with predominantly gastrointestinal AEs, mostly of grade 1 and 2, and they were manageable with dose interruptions and/or reduction. ${ }^{75}$ Grade $\geq 3$ AEs occurred in 106 (85.5\%) of 124 patients and the most common AEs were increases in ALT and $\gamma$-GT (Table 2). Drug-related SAEs were observed in $11 \%$ of patients and $~ 80 \%$ of patients had dose interruptions or adjustments due to AEs. Among the 10 deaths, only 3 were due to AEs, none of which was considered drug related. Updated PRO results were consistent with the primary analysis and showed improvement in symptoms from baseline, and the QoL was maintained.

Phase III studies, ASCEND-4 ${ }^{76}$ and ASCEND-5, ${ }^{77}$ confirmed the overall manageable safety profile of ceritinib (Table 2), with higher frequency of dose interruptions and modifications due to AEs compared to chemotherapy, but lower rates of treatment discontinuation. In both studies, ceritinib improved the lung cancer symptoms and the QoL, compared to chemotherapy.

\section{Acquired resistance to ceritinib}

Ceritinib has been widely demonstrated to have high activity against the most common mutations conferring resistance to crizotinib, including L1196M, G1269A and S1206Y. ${ }^{67}$ Ceritinib has also activity against cell lines with secondary I1171T and V1180L mutations, conferring resistance to both crizotinib and alectinib. ${ }^{86,87}$ However, as observed for crizotinib and other targeted therapies, $A L K$-positive cells can acquire resistance under chronic exposure to ceritinib, thus determining disease progression and limiting its long-term efficacy. Molecular profiling of tumor tissues from rebiopsies obtained at the time of disease progression on ceritinib revealed the presence of novel, acquired mutations at either G1202 or F1174, in 5 of 11 samples analyzed. ${ }^{67}$ Moreover, two different ceritinib resistance mutations were identified within two different biopsy sites in the same patient, underscoring the heterogeneity of ceritinib resistance mechanisms. As commented, the mutation G1202R maps to the solventexposed region of ALK, where the bulkier, charged side chain is thought to lead to steric hindrance of most ALK inhibitors. In the ASCEND-1 study, a patient who was found with G1202R did not respond to ceritinib. ${ }^{73}$ The presence of this mutation confers resistance to ceritinib, while F1174C/L mutations map adjacent to the $\mathrm{C}$ terminus of the $\alpha \mathrm{C}$ helix and may stabilize an active conformation that increases the ATP-binding affinity of ALK. Toyokawa et al identified an ALK G1123S mutation in a patient with $A L K$-positive NSCLC acquiring resistance to ceritinib. Such a mutation located at codon 1123, within the glycine-rich loop, seems to sterically block ATP binding and/or alter the dynamics of the glycine-rich loop, resulting in perturbation of the interactions with ALK inhibitors. ${ }^{88}$

New fundamental insights about the mechanisms of resistance developing during treatment with different ALK inhibitors, including ceritinib, have been provided by a recent in-depth molecular characterization of a large series of repeat postprogression biopsies from $A L K$-positive NSCLC patients. ${ }^{89}$ Overall, $A L K$ resistance mutations represented the predominant mechanism of resistance after progression to next-generation ALK inhibitors; they were present in 56\% of tumor samples, with distinct frequency and patterns of mutations depending on the drug, although the most common was represented by ALK G1202R. Among the 24 ceritinibresistant samples, 54\% showed resistance mutations, the most common being G1202R and F1174C/L (Figure 2). Other mutations included C1156Y, V1180L and the novel G1202del. ${ }^{89}$ Also, an EMT phenotype was identified in 5 of $12(42 \%)$ ceritinib-resistant biopsy specimens, including 
2 cases with the L1196M mutation which does not usually confer resistance to ceritinib. ${ }^{89}$ Interestingly, the potent thirdgeneration ALK inhibitor, lorlatinib, inhibited the growth of ceritinib-resistant patient-derived cell lines harboring $A L K$-resistant mutations, while it had no activity against $A L K$ wild-type cell lines. In addition, lorlatinib was active against cell lines with compound mutations which can occur after sequential treatment with different ALK inhibitors. ${ }^{89}$ Activation of this bypass track has emerged as a possible mechanism of acquired resistance to ceritinib. Indeed, in a tumor sample obtained from a patient after ceritinib progression, a MET amplification was identified..$^{73}$ A recent in vitro study investigated the mechanisms of acquired resistance to alectinib and ceritinib in H3122 NSCLC cell lines harboring the EML4-ALK variant 1 fusion..$^{90}$ Secondary mutations of ALK were not detected; in contrast, overexpression of phospho-ALK and alternative RTKs such as phospho-EGFR, phospho-HER3 and phospho-IGFR-1R was observed in these resistant cell lines. Furthermore, neuregulin 1 (NRG1), a ligand for HER3, was found to be upregulated and responsible for resistance by activating the EGFR family pathways through the NRG1-HER3-EGFR axis. ${ }^{90}$

Finally, P-gp overexpression mediated resistance in $A L K$-rearranged NSCLC patients who received ceritinib or crizotinib therapy, but not alectinib. ${ }^{91}$ Such resistance occurs independent of the presence of ALK mutations and other major activated oncogenes. Indeed, it was demonstrated that brain penetration of ceritinib is strongly restricted by Abcb1a/1b on BBB and by Abcg2 only in the absence of Abcb1a/1b. ${ }^{71}$ Thus, the determination of P-gp expression may provide additional useful information to select the optimal ALK TKI therapy.

\section{Ongoing studies and therapeutic combinations}

After crizotinib, ceritinib was the second ALK inhibitor to receive approval, thus expanding the array of effective therapeutic options for $A L K$-positive NSCLC. However, there is still room for improvement and numerous ongoing trials are investigating whether combinatorial strategies can be more effective than ceritinib as a single agent for improving the outcome of $A L K$-rearranged NSCLC patients (Table 3). Heat shock protein 90 (Hsp90) is a chaperone protein that regulates the folding, stabilization and function of not only different client proteins, including the growth factors and signaling molecules, but also of oncogenic kinases including EGFR, BRAF, c-MET and EML4/ALK. ${ }^{92}$ Preclinical data demonstrated that Hsp90 inhibitors were effective against cell lines and xenograft models positive for the EML4-ALK fusion gene. In $A L K$-driven NSCLC cells and xenografts of NSCLC resistant to ALK inhibitors, superior antitumor efficacy was observed when combining the Hsp90 inhibitor

Table 3 Summary of selected ongoing trials of ceritinib (LDK378) in NSCLC

\begin{tabular}{|c|c|c|c|}
\hline Clinical trial & Phase & Full title & Recruitment status* \\
\hline NCT0232I50I & $\mathrm{l} / \mathrm{lb}$ & $\begin{array}{l}\text { Dose escalation \& biomarker study of ceritinib (LDK378) in combination with everolimus } \\
\text { in patients with locally advanced or metastatic solid tumors with an expansion in NSCLC } \\
\text { characterized by abnormalities in ALK expression }\end{array}$ & Currently recruiting \\
\hline NCT0I947608 & $\begin{array}{l}\text { Expanded } \\
\text { access }\end{array}$ & $\begin{array}{l}\text { Open-label, multi-center, Expanded Treatment Protocol (ETP) of oral LDK378 in adult } \\
\text { patients with NSCLC characterized by ALK positivity }\end{array}$ & Available \\
\hline NCT0I772797 & $\mathrm{lb}$ & $\begin{array}{l}\text { Open-label, dose escalation study of LDK378 and AUY } 922 \text { in patients with ALK- } \\
\text { rearranged NSCLC }\end{array}$ & Completed \\
\hline NCT02292550 & $\mathrm{I} / \mathrm{II}$ & $\begin{array}{l}\text { A Phase Ib/II study of the ALK inhibitor ceritinib in combination with the CDK4/6 } \\
\text { inhibitor LEEOII in patients with ALK-positive NSCLC }\end{array}$ & Currently recruiting \\
\hline NCT02040870 & $\mathrm{I} / \mathrm{II}$ & $\begin{array}{l}\text { A Phase I/II, multicenter, open-label, single-arm study of LDK378, administered orally in } \\
\text { adult Chinese patients with ALK-rearranged (ALK-positive) advanced NSCLC previously } \\
\text { treated with crizotinib }\end{array}$ & Ongoing, not recruiting \\
\hline NCT02393625 & I & $\begin{array}{l}\text { A multi-center, open-label study to assess the safety and efficacy of combination ceritinib } \\
\text { and nivolumab in adult patients with ALK + NSCLC }\end{array}$ & Currently recruiting \\
\hline NCT025I3667 & ॥ & $\begin{array}{l}\text { Phase II trial of ceritinib in combination with stereotactic ablative radiation in ALK- } \\
\text { rearranged metastatic lung adenocarcinoma }\end{array}$ & Currently recruiting \\
\hline NCT0233645I & ॥ & $\begin{array}{l}\text { A Phase II, multi-center, open-label, five-arm study to evaluate the efficacy and safety of } \\
\text { oral ceritinib treatment for patients with ALK-positive NSCLC metastatic to the brain } \\
\text { and/or to leptomeninges }\end{array}$ & Currently recruiting \\
\hline NCT02276027 & II & $\begin{array}{l}\text { A Phase II, open-label, multiple arm study of single agent AUY922, BYL7I9, INC280, } \\
\text { LDK378 and MEKI62 in Chinese patients with advanced NSCLC\# }\end{array}$ & Currently recruiting \\
\hline
\end{tabular}

Notes: *Based on information available from https://www. ClinicalTrials.gov. "Selection of targeted agent is based on the presence of specific molecular alteration in tumors. Abbreviations: ALK, anaplastic lymphoma kinase; NSCLC, non-small cell lung cancer. 
ganetespib with other targeted ALK agents. ${ }^{93}$ Ganetespib overcame crizotinib resistance due to multiple forms of resistance, including $A L K$ secondary mutations. In a Phase II trial of ganetespib in advanced NSCLC patients, in a cohort of 23 patients with NSCLC, wild type for both EGFR and KRAS, $A L K$ rearrangements were found in 8 patients. Of these, four had partial response and three had stable disease. ${ }^{94}$ Another potent HSP90 inhibitor, luminespib (AUY922), demonstrated significant activity in crizotinib-naïve and crizotinib-resistant patients in an initial Phase II trial, with the most common all grade toxicities being eye disorders, diarrhea and nausea. ${ }^{95}$ However, in another more recent Phase II trial of luminespib monotherapy in $A L K$-positive patients who had progressed on prior ALK TKIs, no objective responses were observed among the six patients enrolled. Despite the low number of patients and premature closure of the study, these results suggest that monotherapy with this HSP90 inhibitor may not be a valid treatment option in this setting. ${ }^{96}$ A Phase Ib, open-label, dose escalation study evaluating the combination of ceritinib and luminespib in crizotinib-resistant, $A L K$-rearranged NSCLC patients (NCT01772797) has been completed and its results are pending (Table 3 ).

Other possible therapeutic combinations to overcome or delay resistance to ceritinib are suggested by in vitro studies, such as the potential of combining the irreversible EGFR TKI, afatinib, with ceritinib in those cases of resistance mediated by activation of EGFR family pathways. ${ }^{90}$

A Phase Ib/II study of the ALK inhibitor ceritinib in combination with the CDK4/6 inhibitor LEE011 (ribociclib) in patients with $A L K$-positive NSCLC is currently recruiting participants. The purpose of this study is to determine the MTD/recommended phase 2 dose (RP2D) of ribociclib and ceritinib combination and to evaluate whether this combination is safe and has activity in $A L K$-positive advanced NSCLC patients, who are ALK-inhibitor-naïve or have progressed after treatment with an ALK inhibitor other than ceritinib or after treatment with ceritinib (NCT02292550). The introduction of immune checkpoint inhibitors, including monoclonal antibodies directed against the cytotoxic T-lymphocyte-associated antigen-4 and the programmed cell death protein-1/programmed cell death ligand-1 (PD-1/ PD-L1) pathways, has improved the treatment of advanced NSCLC, especially for those patients without targetable activated oncogenes. ${ }^{97}$ There is strong scientific rationale for sequentially or concurrently combining ALK inhibitors with immune checkpoint blockade. ${ }^{45,98,99}$ However, recent data from clinical trials suggest that anti-PD-1/PD-L1 antibodies are less effective in never-smokers, which is the population enriched for EGFR mutations or ALK rearrangements, compared to smokers, probably for increased tumor immunogenicity due to a higher mutational load in smokingassociated lung cancer. ${ }^{97}$ Moreover, poor responses to PD-1/ PD-L1 inhibitors have been observed in EGFR-mutated or $A L K$-rearranged NSCLC patients and this can be explained by low rates of concurrent PD-L1 expression and CD8(+) tumor-infiltrating lymphocytes (TILs) within the tumor microenvironment. ${ }^{100}$ Some ongoing studies are evaluating the combination of ALK inhibitors and checkpoint inhibitors, including an open-label, multicenter, Phase I trial of ceritinib in combination with the anti-PD1 monoclonal antibody, nivolumab, in $A L K$-positive, stage IIIB or IV NSCLC. Primary outcome measures are MTD and/or recommended dose for the expansion phase and ORR. Secondary outcome measures include DOR, DCR and OS (NCT02393625). We should mention that molecular docking simulations and preclinical studies demonstrate that ceritinib may also be active against ROS1-rearranged NSCLC and some clinical reports confirm this activity. ${ }^{66,101,102}$ Ongoing studies are evaluating the role of ceritinib in this subset of patients (Table 3 ).

\section{Discussion and conclusion}

Since the approval of the first-in-class ALK inhibitor, crizotinib, in 2011, the landscape of treatment for $A L K$-positive NSCLC has rapidly evolved over the last few years, thus leading to a significant improvement in the prognosis of this molecularly defined subset of NSCLC patients.

Crizotinib was approved based on pronounced clinical benefit observed in early-phase studies in $A L K$-rearranged NSCLC patients. However, despite its remarkable activity, the vast majority of patients inevitably progress due to acquired resistance, with the brain being a common site of relapse. The most common mechanisms underlying acquired resistance have been characterized, and these include $A L K$ secondary mutations or copy number alterations and activation of alternative bypass signaling pathways. In order to face the major shortcomings of crizotinib, various next-generation ALK inhibitors have been developed and are currently at different phases of clinical development. These are structurally distinct, have higher potency against ALK and ALK with resistance mutations and improved $\mathrm{BBB}$ penetration, compared to crizotinib. Ceritinib, a highly potent and selective ALK inhibitor, was the first to be approved by the FDA in 2014 for the treatment of $A L K$-positive NSCLC patients with progression, or who are intolerant to crizotinib, based on pronounced clinical activity observed in the Phase I ASCEND-1 trial, and it is currently approved in the European Union and in several 
countries worldwide with this indication. In Phase I and II studies, ceritinib treatment produced significant objective responses in both crizotinib-resistant and crizotinib-naïve $A L K$-positive NSCLC patients, and recent results from Phase III studies have demonstrated that ceritinib significantly improves PFS compared with standard chemotherapy in the first- and second-line treatment setting of $A L K$-positive, advanced NSCLC patients, with associated significant improvements in QoL and lung cancer symptoms. Thus, this great amount of data suggests that ceritinib is a solid therapeutic choice in crizotinib-resistant $A L K$-positive NSCLC patients, including those with CNS involvement. Sequential crizotinib and ceritinib in a multi-institutional retrospective analysis was associated with a PFS of 17.4 months and an impressive OS of 49.4 months, suggesting that sequential use of different ALK inhibitors is an effective strategy in $A L K$ positive NSCLC patients. ${ }^{103}$ Despite the success of ceritinib in clinical development, other available next-generation inhibitors have shown robust clinical activity in crizotinibpretreated patients, including alectinib, which has already been approved by the FDA and the EMA, and brigatinib, which has received breakthrough therapy designation by the FDA. Notably, the activity of these next-generation ALK inhibitors has been also observed in crizotinib-naïve patients, and alectinib and brigatinib are currently being investigated in Phase III studies in a head-to-head comparison with crizotinib in ALK-inhibitor-naïve patients.

Therefore, since ceritinib has gained an unquestionable role in the therapeutic algorithm of $A L K$-positive NSCLC patients, with the availability of new and active next-generation ALK inhibitors, selecting the appropriate sequence of ALK TKIs has become a crucial factor to improve patient outcomes. After crizotinib failure, some important points can be helpful in guiding selection between the two clinically approved next-generation ALK inhibitors, ceritinib or alectinib. One is the intracranial activity of these compounds. Indeed, alectinib is not a P-gp substrate and can achieve higher CNS levels compared to ceritinib or crizotinib, thereby improving CNS disease control, as demonstrated in clinical studies. ${ }^{71,79,81}$ Therefore, alectinib can be considered a preferred option for $A L K$-positive NSCLC patients with CNS progression. Also, the side effect profile is slightly different between ceritinib and alectinib, with clinical data suggesting alectinib is overall better tolerated than ceritinib. Recent data suggest that treatment choice at progression should be guided by underlying resistance mutations. Indeed, ceritinib is not only able to overcome the most common crizotinib-resistant mutations, but also has activity against some mutations conferring resistance to alectinib. ${ }^{67,86,87}$ However, acquired resistance to ceritinib may eventually occur, with secondary $A L K$ mutations being the most common mechanism of resistance found in postprogression patient samples. G1202R and F1174C/L represent the predominant resistance mutations after ceritinib treatment. ${ }^{89}$ The F1174 mutation confers resistance to ceritinib, but is still sensitive to alectinib, while the G1202R is resistant to most next-generation ALK inhibitors, except lorlatinib. This potent third-generation ALK inhibitor was able to inhibit the growth of ceritinib-resistant patient-derived cell lines harboring $A L K$ resistance mutations, including G1202R, and was also active against cell lines with compound mutations, which occur when patients are sequentially treated with different ALK TKIs. ${ }^{89}$ Of note, in a recent report, a secondary mutation conferring resistance to lorlatinib was identified, and this mutation, ALK L1198F, paradoxically enhanced binding to crizotinib, thus resensitizing resistant cancers to crizotinib. ${ }^{104}$ Overall, these data corroborate the use of molecular profiling at disease progression to match the treatment choice to each acquired mutation. In those cases in which resistance to ceritinib is associated with ALK-independent mechanisms, such as activation of alternative kinases involved in proliferation signaling pathways or epithelial-mesenchymal transition (EMT), rational combinations of drugs can represent a promising therapeutic option, as suggested by some preclinical evidence. Some studies are currently evaluating combinations of immune checkpoint inhibitors with ALK inhibitors, and results in terms of activity and toxicity of these novel combinations are also eagerly awaited.

\section{Disclosure}

The authors report no conflicts of interest in this work.

\section{References}

1. Ferlay J, Soerjomataram I, Dikshit R, et al. Cancer incidence and mortality worldwide: sources, methods and major patterns in GLOBOCAN 2012. Int J Cancer. 2015;136(5):E359-E386.

2. Sandler A, Gray R, Perry MC, et al. Paclitaxel-carboplatin alone or with bevacizumab for non-small-cell lung cancer. NEJM. 2006;355(24): $2542-2550$.

3. Reck M, von Pawel J, Zatloukal P, et al. Phase III trial of cisplatin plus gemcitabine with either placebo or bevacizumab as first-line therapy for nonsquamous non-small-cell lung cancer: AVAil. J Clin Oncol. 2009;27(8):1227-1234.

4. Thatcher N, Hirsch FR, Luft AV, et al; SQUIRE Investigators. Necitumumab plus gemcitabine and cisplatin versus gemcitabine and cisplatin alone as first-line therapy in patients with stage IV squamous non-smallcell lung cancer (SQUIRE): an open-label, randomised, controlled phase 3 trial. Lancet Oncol. 2015;16(7):763-774.

5. Politi K, Herbst RS. Lung cancer in the era of precision medicine. Clin Cancer Res. 2015;21(10):2213-2220.

6. Santarpia M, Altavilla G, Salazar MF, et al. Tyrosine kinase inhibitors for non-small-cell lung cancer: finding patients who will be responsive. Expert Rev Respir Med. 2011;5(3):413-424. 
7. Riely GJ, Yu HA. EGFR: the paradigm of an oncogene-driven lung cancer. Clin Cancer Res. 2015;21(10):2221-2226.

8. Katayama R, Lovly CM, Shaw AT. Therapeutic targeting of anaplastic lymphoma kinase in lung cancer: a paradigm for precision cancer medicine. Clin Cancer Res. 2015;21(10):2227-2235.

9. Masters GA, Temin S, Azzoli CG, et al. Systemic therapy for stage IV non-small-cell lung cancer: American Society of Clinical Oncology Clinical Practice Guideline Update. J Clin Oncol. 2015;33(30):3488-3515.

10. Soda M, Choi YL, Enomoto M, et al. Identification of the transforming EML4-ALK fusion gene in non-small-cell lung cancer. Nature. 2007;448(7153):561-566.

11. Iwahara T, Fujimoto T, Wen D, et al. Molecular characterization of ALK, a receptor tyrosine kinase espressed specifically in the nervous system. Oncogene. 1997;14(4):439-449.

12. Chiarle R, Voena $\mathrm{C}$, Ambrogio $\mathrm{C}$, Piva R, Inghirami G. The anaplastic lymphoma kinase in the pathogenesis of cancer. Nat Rev Cancer. 2008; 8(1):11-23.

13. Palmeri RH, Vernersson E, Grabbe C, Hallberg B. Anaplastic lymphoma kinase: signalling in development and disease. Biochem J. 2009; 420(3):345-361.

14. Stoica GE, Kuo A, Aigner A, et al. Identification of anaplastic lymphoma kinase as receptor for the growth factor pleiotrophin. $J$ Biol Chem. 2001;276(20):16772-16779.

15. Stoica GE, Kuo A, Powers C, et al. Midkine binds to anaplastic lymphoma kinase (ALK) and acts as a growth factor for different cell types. J Biol Chem. 2002;277(39):35990-35998.

16. Hallberg B, Palmer RH. Mechanistic insight into ALK receptor tyrosine kinase in human cancer biology. Nat Rev Cancer. 2013;13(10):685-700.

17. Soda M, Takada S, Takeuchi K, et al. A mouse model for EML4ALK-positive lung cancer. Proc Natl Acad Sci U S A. 2008;105(50): 19893-19897.

18. McDermott U, Iafrate AJ, Gray NS, et al. Genomic alterations of anaplastic lymphoma kinase may sensitize tumors to anaplastic lymphoma kinase inhibitors. Cancer Res. 2008;68(9):3389-3395.

19. Sasaki T, Rodig SJ, Chirieac LR, et al. The biology and treatment of EML4-ALK non-small cell lung cancer. Eur J Cancer. 2010;46(10): 1773-1780.

20. Choi YL, Takeuchi K, Soda M, et al. Identification of novel isoforms of the EML4-ALK transforming gene in non-small cell lung cancer. Cancer Res. 2008;68(13):4971-4976.

21. Koivunen JP, Mermel C, Zejnullahu K, et al. EML4-ALK fusion gene and efficacy of an ALK kinase inhibitor in lung cancer. Clin Cancer Res. 2008;14(13):4275-4283.

22. Galkin AV, Melnick JS, Kim S, et al. Identification of NVP-TAE684, a potent, selective, and efficacious inhibitor of NPM-ALK. Proc Natl Acad Sci U S A. 2007;104(1):270-275.

23. Heuckmann JM, Balke-Want H, Malchers F, et al. Differential protein stability and ALK inhibitor sensitivity of EML4-ALK fusion variants Clin Cancer Res. 2012;18(17):4682-4690.

24. Yoshida T, Oya Y, Tanaka K, et al. Differential crizotinib response duration among ALK fusion variants in ALK-positive non-small-cell lung cancer. J Clin Oncol. 2016;34(28):3383-3389.

25. Rikova K, Guo A, Zeng Q, et al. Global survey of phosphotyrosine signaling identifies oncogenic kinases in lung cancer. Cell. 2007, 131(6):1190-1203.

26. Takeuchi K, Choi YL, Togashi Y, et al. KIF5B-ALK, a novel fusion oncokinase identified by an immunohistochemistry-based diagnostic system for ALK-positive lung cancer. Clin Cancer Res. 2009;15(9):3143-3149.

27. Togashi Y, Soda M, Sakata S, et al. KLC1-ALK: a novel fusion in lung cancer identified using a formalin-fixed paraffin-embedded tissue only. PLoS One. 2012;7(2):e31323.

28. Choi YL, Lira ME, Hong M, et al. A novel fusion of TPR and ALK in lung adenocarcinoma. J Thorac Oncol. 2014;9(4):563-566.

29. Ou SH, Klempner SJ, Greenbowe JR, et al. Identification of a novel HIP1ALK fusion variant in non-small-cell lung cancer (NSCLC) and discovery of ALK I1171 (I1171N/S) mutations in two ALK-rearranged NSCLC patients with resistance to alectinib. J Thorac Oncol. 2014;9(12):1821-1825.
30. Shan L, Jiang P, Xu F, et al. BIRC6-ALK, a novel fusion gene in ALK break-apart FISH-negative lung adenocarcinoma, responds to crizotinib. J Thorac Oncol. 2015;10:e37-e39.

31. Shaw AT, Yeap BY, Mino-Kenudson M, et al. Clinical features and outcome of patients with non-small-cell lung cancer who harbor EML4ALK. J Clin Oncol. 2009;27(26):4247-4253.

32. Lazzari C, Spitaleri G, Catania C, et al. Targeting ALK in patients with advanced non small cell lung cancer: biology, diagnostic and therapeutic options. Crit Rev Oncol Hematol. 2014;89(3):358-365.

33. Gainor JF, Varghese AM, Ou SH, et al. ALK rearrangements are mutually exclusive with mutations in EGFR or KRAS: an analysis of 1,683 patients with non-small cell lung cancer. Clin Cancer Res. 2013; 19(15):4273-4281.

34. Pekar-Zlotin M, Hirsch FR, Soussan-Gutman L, et al. Fluorescence in situ hybridization, immunohistochemistry, and next-generation sequencing for detection of EML4-ALK rearrangement in lung cancer. Oncologist. 2015;20(3):316-322.

35. Wynes MW, Sholl LM, Dietel M, et al. An international interpretation study using the ALK IHC antibody D5F3 and a sensitive detection kit demonstrates high concordance between ALK IHC and ALK FISH and between evaluators. $J$ Thorac Oncol. 2014;9(5):631-638.

36. Rogers TM, Russell PA, Wright G, et al. Comparison of methods in the detection of ALK and ROS1 rearrangements in lung cancer. $J$ Thorac Oncol. 2015;10(4):611-618.

37. Marchetti A, Di Lorito A, Pace MV, et al. ALK protein analysis by IHC staining after recent regulatory changes: a comparison of two widely used approaches, revision of the literature, and a new testing algorithm. J Thorac Oncol. 2016;11(4):487-495.

38. Christensen JG, Zou HY, Arango ME, et al. Cytoreductive antitumor activity of PF 2341066, a novel inhibitor of anaplastic lymphoma kinase and c-Met, in experimental models of anaplastic large-cell lymphoma. Mol Cancer Ther. 2007;6(12 Pt 1):3314-3322.

39. Cui JJ, Tran-Dubé M, Shen H, et al. Structure based drug design of crizotinib (PF 02341066), a potent and selective dual inhibitor of mesenchymal-epithelial transition factor (c-MET) kinase and anaplastic lymphoma kinase (ALK). J Med Chem. 2011;54(18):6342-6363.

40. Kwak EL, Bang YJ, Camidge DR, et al. Anaplastic lymphoma kinase inhibition in non-small-cell lung cancer. $N$ Engl J Med. 2010; 363(18):1693-1703.

41. Camidge DR, Bang YJ, Kwak EL, et al. Activity and safety of crizotinib in patients with ALK-positive non-small-cell lung cancer: updated results from a phase 1 study. Lancet Oncol. 2012;13(10): 1011-1019.

42. Kim DW, Ahn MJ, Yang PC, et al. Updated results of a global phase II study with crizotinib in advanced ALK-positive non-small cell lung cancer (NSCLC). Ann Oncol. 2012;23(Suppl 9):ix400-ix446.

43. Shaw AT, Kim DW, Nakagawa K, et al. Crizotinib versus chemotherapy in advanced ALK-positive lung cancer. $N$ Engl $J$ Med. 2013;368(25): 2385-2394.

44. Solomon BJ, Mok T, Kim DW, et al. First-line crizotinib versus chemotherapy in ALK-positive lung cancer. N Engl J Med. 2014;371(23): 2167-2177.

45. Santarpia M, Gil N, Rosell R. Strategies to overcome resistance to tyrosine kinase inhibitors in non-small-cell lung cancer. Expert Rev Clin Pharmacol. 2015;8(4):461-477.

46. Costa DB, Kobayashi S, Pandya SS, et al. CSF concentration of the anaplastic lymphoma kinase inhibitor crizotinib. J Clin Oncol. 2011;29(15):e443-e445.

47. Chun SG, Choe KS, Iyengar P, Yordy JS, Timmerman RD. Isolated central nervous system progression on Crizotinib: an Achilles heel of non-small cell lung cancer with EML4-ALK translocation? Cancer Biol Ther. 2012;13(14):1376-1383.

48. Tang SC, Nguyen LN, Sparidans RW, Wagenaar E, Beijnen JH, Schinkel AH. Increased oral availability and brain accumulation of the ALK inhibitor crizotinib by coadministration of the P-glycoprotein $(\mathrm{ABCB} 1)$ and breast cancer resistance protein (ABCG2) inhibitor elacridar. Int J Cancer. 2014;134(6):1484-1494. 
49. Dagogo-Jack I, Shaw AT. Crizotinib resistance: implications for therapeutic strategies. Ann Oncol. 2016;27(Suppl 3):iii42-iii50.

50. Doebele RC, Pilling AB, Aisner DL, et al. Mechanisms of resistance to crizotinib in patients with ALK gene rearranged non-small cell lung cancer. Clin Cancer Res. 2012;18(5):1472-1482.

51. Katayama R, Shaw AT, Khan TM, et al. Mechanisms of acquired crizotinib resistance in ALK-rearranged lung cancers. Sci Transl Med. 2012;4(120):120ra17.

52. Choi YL, Soda M, Yamashita Y, et al. EML4-ALK mutations in lung cancer that confer resistance to ALK inhibitors. $N$ Engl $J$ Med. 2010;363(18):1734-1739.

53. Sasaki T, Koivunen J, Ogino A, et al. A novel ALK secondary mutation and EGFR signaling cause resistance to ALK kinase inhibitors. Cancer Res. 2011;(18):6051-6060.

54. Toyokawa G, Hirai F, Inamasu E, et al. Secondary mutations at I1171 in the ALK gene confer resistance to both Crizotinib and Alectinib. J Thorac Oncol. 2014;9(12):e86-e87.

55. Ou SH, Azada M, Hsiang DJ, et al. Next-generation sequencing reveals a novel NSCLC ALK F1174V mutation and confirms ALK G1202R mutation confers high-level resistance to alectinib (CH5424802/ RO5424802) in ALK-rearranged NSCLC patients who progressed on crizotinib. J Thorac Oncol. 2014;9(4):549-553.

56. Kim S, Kim TM, Kim DW, et al. Heterogeneity of genetic changes associated with acquired crizotinib resistance in ALK-rearranged lung cancer. J Thorac Oncol. 2013;8(4):415-422.

57. Tanizaki J, Okamoto I, Okabe T, et al. Activation of HER family signaling as a mechanism of acquired resistance to ALK inhibitors in EML4ALK-positive non-small cell lung cancer. Clin Cancer Res. 2012;18: 6219-6226.

58. Kimura M, Endo M, Inoue T, et al. Analysis of ERBB ligand-induced resistance mechanism to crizotinib by primary culture of lung adenocarcinoma with EML4-ALK fusion gene. J Thorac Oncol. 2015; 10(3):527-530.

59. Lovly CM, McDonald NT, Chen H, et al. Rationale for co-targeting IGF-1R and ALK in ALK fusion-positive lung cancer. Nat Med. 2014; 20(9):1027-1034.

60. Crystal AS, Shaw AT, Sequist LV, et al. Patient-derived models of acquired resistance can identify effective drug combinations for cancer. Science. 2014;346(6216):1480-1486.

61. Hrustanovic G, Olivas V, Pazarentzos E, et al. RAS-MAPK dependence underlies a rational polytherapy strategy in EML4-ALK-positive lung cancer. Nat Med. 2015;21(9):1038-1047.

62. Galkin AV, Melnick JS, Kim S, et al. Identification of NVP-TAE684, a potent, selective, and efficacious inhibitor of NPM-ALK. Proc Natl Acad Sci U S A. 2007;104(1):270-275.

63. Marsilje TH, Pei W, Chen B, et al. Synthesis, structure-activity relationships, and in vivo efficacy of the novel potent and selective anaplastic lymphoma kinase (ALK) inhibitor 5 chloro-N2-(2-isopropoxy5-methyl-4-(piperidin-4-yl)phenyl)-N4-(2 (isopropylsulfonyl)phenyl) pyrimidine-2,4-diamine (LDK378) currently in phase 1 and phase 2 clinical trials. J Med Chem. 2013;56(14):5675-5690.

64. Chen J, Jiang C, Wang S. LDK378: a promising anaplastic lymphoma kinase (ALK) inhibitor. J Med Chem. 2013;56(14):5673-5674.

65. Shaw AT, Mehra R, Kim DW, et al. Clinical activity of the ALK Inhibitor LDK378 in advanced, ALK-positive NSCL. Presented at the Annual Meeting of the American Society of Clinical Oncology; May 31-June 4, 2013; Chicago. Abstract.

66. ZYKADIA ${ }^{\mathrm{TM}}$ (ceritinib) capsules, for oral use: US prescribing information. 2014. Available from: https://www.pharma.us.novartis.com/sites/www. pharma.us.novartis.com/files/zykadia.pdf. Accessed March 1, 2017.

67. Friboulet L, Li N, Katayama R, et al. The ALK inhibitor ceritinib overcomes crizotinib resistance in non-small cell lung cancer. Cancer Discov. 2014;4(6):662-673.

68. Shaw A, Kim D, Mehra R, et al. Ceritinib in ALK-rearranged nonsmall-cell lung cancer. N Engl J Med. 2014;370(13):1189-1197.

69. Lau YY, Gu W, Lin T, Song D, Yu R, Scott JW. Effects of meal type on the oral bioavailability of the ALK inhibitor ceritinib in healthy adult subjects. J Clin Pharmacol. 2016;56(5):559-566.
70. Khozin S, Blumenthal GM, Zhang L, et al. FDA approval: ceritinib for the treatment of metastatic anaplastic lymphoma kinase-positive nonsmall cell lung cancer. Clin Cancer Res. 2015;21(11):2436-2439.

71. Kort A, Sparidans RW, Wagenaar E, Beijnen JH, Schinkel AH. Brain accumulation of the EML4-ALK inhibitor ceritinib is restricted by P-glycoprotein (P-GP/ABCB1) and breast cancer resistance protein (BCRP/ABCG2). Pharmacol Res. 2015;102:200-207.

72. Kim DW, Mehra R, Tan DS, et al. Activity and safety of ceritinib in patients with ALK-rearranged non-small-cell lung cancer (ASCEND-1): updated results from the multicentre, open-label, phase 1 trial. Lancet Oncol. 2016;17(4):452-463.

73. Tan DS, Kim DW, Thomas M, et al. Genetic landscape of ALK+ nonsmall cell lung cancer (NSCLC) patients (pts) and response to ceritinib in ASCEND-1. J Clin Oncol. 2016;34(suppl; abstr 9064); ASCO Meet Abstr.

74. Crinò L, Ahn MJ, De Marinis F, et al. Multicenter Phase II study of whole-body and intracranial activity with ceritinib in patients with ALK-rearranged non-small-cell lung cancer previously treated with chemotherapy and crizotinib: results from ASCEND-2. J Clin Oncol. 2016;34(24):2866-2873.

75. Felip E, Orlov $S$, Park K, et al. Phase 2 study of ceritinib in ALKi-naïve patients (pts) with ALK-rearranged (ALK+) non-small cell lung cancer (NSCLC): Whole body responses in the overall pt group and in pts with baseline brain metastases (BM). Presented at: The ESMO Congress 2016 (abstr 1208O), October 7-11; 2016; Copenhagen, Denmark.

76. Soria JC, Tan DS, Chiari R, et al. First-line ceritinib versus platinumbased chemotherapy in advanced ALK-rearranged non-small-cell lung cancer (ASCEND-4): a randomised, open-label, phase 3 study. Lancet. 2017;389(10072):917-929.

77. Scagliotti G, Kim T, Crinò L, et al. Ceritinib versus chemotherapy (CT) in patients (pts) with advanced anaplastic lymphoma kinase (ALK)rearranged $(\mathrm{ALK}+)$ non-small cell lung cancer (NSCLC) previously treated with CT and crizotinib (CRZ): Results from the confirmatory phase 3 ASCEND-5 study. Presented at the ESMO Congress 2016 (abstr LBA42_PR); October 7-11; 2016; Copenhagen, Denmark.

78. Costa DB, Shaw AT, Ou SH, et al. Clinical experience with crizotinib in patients with advanced ALK-rearranged non-small-cell lung cancer and brain metastases. J Clin Oncol. 2015;10;33(17):1881-1888.

79. Gadgeel SM, Shaw AT, Govindan R, et al. Pooled analysis of CNS response to alectinib in two studies of pretreated patients with ALKpositive non-small-cell lung cancer. J Clin Oncol. 2016;34(34): 4079-4085.

80. Gettinger SN, Bazhenova LA, Langer CJ, et al. Activity and safety of brigatinib in ALK-rearranged non-small-cell lung cancer and other malignancies: a single-arm, open-label, phase 1/2 trial. Lancet Oncol. 2016;17(12):1683-1696.

81. Santarpia M, Altavilla G, Rosell R. Alectinib a selective, next-generation ALK inhibitor for treatment of ALK-rearranged non-small-cell lung cancer. Expert Rev Respir Med. 2015;9(3):255-268.

82. Zhang S, Anjum R, Squillace R, et al. The potent ALK inhibitor brigatinib (AP26113) overcomes mechanisms of resistance to first- and second-generation ALK inhibitors in preclinical models. Clin Cancer Res. 2016;22(22):5527-5538.

83. Johnson TW, Richardson PF, Bailey S, et al. Discovery of (10R)-7amino-12-fluoro-2,10,16-trimethyl-15-oxo-10,15,16,17-tetrahydro-2H8,4-(metheno)pyrazolo[4,3-h][2,5,11]-benzoxadiazacyclotetradecine3-carbonitrile (PF-06463922), a macrocyclic inhibitor of anaplastic lymphoma kinase (ALK) and c-ros oncogene 1 (ROS1) with preclinical brain exposure and broad-spectrum potency against ALK-resistant mutations. J Med Chem. 2014;57(11):4720-4744.

84. Zou HY, Friboulet L, Kodack DP, et al. PF-06463922, an ALK/ROS1 inhibitor, overcomes resistance to first and second generation ALK inhibitors in preclinical models. Cancer Cell. 2015;28(1):70-81.

85. Felip E, Bauer TM, Solomon B, et al. Safety and Efficacy of Lorlatinib (PF-06463922) in Patients with Advanced ALK+ or ROS1+ Non-Small-Cell Lung Cancer (NSCLC). Presented at the IASLC 17th World Congress on Lung Cancer (abstr ID 5053); December 4-7, 2016; Vienna, Austria. 
86. Toyokawa G, Hirai F, Inamasu E, et al. Secondary mutations at I1171 in the ALK gene confer resistance to both crizotinib and alectinib. J Thorac Oncol. 2014;9(12):e86-e87.

87. Katayama R, Friboulet L, Koike S, et al. Two novel ALK mutations mediate acquired resistance to the next-generation ALK inhibitor alectinib. Clin Cancer Res. 2014;20(22):5686-5696.

88. Toyokawa G, Inamasu E, Shimamatsu S, et al. Identification of a novel ALK G1123S mutation in a patient with ALK-rearranged non-smallcell lung cancer exhibiting resistance to ceritinib. J Thorac Oncol. 2015;10(7):e55-e57.

89. Gainor JF, Dardaei L, Yoda S, et al. Molecular mechanisms of resistance to first- and second-generation ALK inhibitors in ALK-rearranged lung cancer. Cancer Discov. 2016;6(10):1118-1133.

90. Dong X, Fernandez-Salas E, Li E, Wang S. Elucidation of resistance mechanisms to second-generation ALK inhibitors alectinib and ceritinib in non-small cell lung cancer cells. Neoplasia. 2016;18(3):162-171.

91. Katayama R, Sakashita T, Yanagitani N, et al. P-glycoprotein mediates ceritinib resistance in anaplastic lymphoma kinase-rearranged non-small cell lung cancer. EBioMedicine. 2016;3:54-66.

92. Trepel J, Mollapour M, Giaccone G, Neckers L. Targeting the dynamic HSP90 complex in cancer. Nat Rev Cancer. 2010;10(8):537-549.

93. Chen Z, Sasaki T, Tan X, et al. Inhibition of ALK, PI3K/MEK, and HSP90 in murine lung adenocarcinoma induced by EML4-ALK fusion oncogene. Cancer Res. 2010;70(23):9827-9836.

94. Socinski MA, Goldman J, El-Hariry I, et al. A multicenter phase II study of ganetespib monotherapy in patients with genotypically defined advanced non-small cell lung cancer. Clin Cancer Res. 2013;19(11): 3068-3077.

95. Felip E, Carcereny E, Barlesi F. Phase II activity of the Hsp90 inhibitor AUY922 in patients with ALK-rearranged (ALK+) or EGFRmutated advanced non-small cell lung cancer (NSCLC). Ann Oncol. 2012;23(Supp1 9):ix152-ix174, 438.
96. Gainor JF, Marcoux JP, Rabin M, et al. A phase II trial of AUY922, a heat shock protein 90 (HSP90) inhibitor, in ALK-positive lung cancer patients previously treated with ALK inhibitors. J Thorac Oncol. 2015;10(Suppl 2):S66-S890.

97. Santarpia M, Giovannetti E, Rolfo C, et al. Recent developments in the use of immunotherapy in non-small cell lung cancer. Expert Rev Respir Med. 2016;10(7):781-798.

98. Vanneman M, Dranoff G. Combining immunotherapy and targeted therapies in cancer treatment. Nat Rev Cancer. 2012;12(4):237-251.

99. Ota K, Azuma K, Kawahara A, et al. Induction of PD-L1 expression by the EML4- ALK oncoprotein and downstream signaling pathways in non-small cell lung cancer. Clin Cancer Res. 2015;21(17): 4014-4021.

100. Gainor JF, Shaw AT, Sequist LV, et al. EGFR mutations and ALK rearrangements are associated with low response rates to PD-1 pathway blockade in non-small cell lung cancer: a retrospective analysis. Clin Cancer Res. 2016;22(18):4585-4593.

101. Davare MA, Vellore NA, Wagner JP, et al. Structural insight into selectivity and resistance profiles of ROS1 tyrosine kinase inhibitors Proc Natl Acad Sci U S A. 2015;112(39):E5381-E5390.

102. Subbiah V, Hong DS, Meric-Bernstama F. Clinical activity of ceritinib in ROS1-rearranged non-small cell lung cancer: bench to bedside report. Proc Natl Acad Sci US A. 2016;113(11):E1419-E1420.

103. Gainor JF, Tan DS, De Pas T, et al. Progression-free and overall survival in ALK-positive NSCLC patients treated with sequential crizotinib and ceritinib. Clin Cancer Res. 2015;21(12):2745-2752.

104. Shaw AT, Friboulet L, Leshchiner I, et al. Resensitization to crizotinib by the lorlatinib ALK resistance mutation L1198F. $N$ Engl J Med. 2016;374(1):54-61.

\section{Publish your work in this journal}

Drug Design, Development and Therapy is an international, peerreviewed open-access journal that spans the spectrum of drug design and development through to clinical applications. Clinical outcomes, patient safety, and programs for the development and effective, safe, and sustained use of medicines are the features of the journal, which

\section{Dovepress}

has also been accepted for indexing on PubMed Central. The manuscript management system is completely online and includes a very quick and fair peer-review system, which is all easy to use. Visit http://www.dovepress.com/testimonials.php to read real quotes from published authors.

Submit your manuscript here: http://www.dovepress.com/drug-design-development-and-therapy-journal 